\title{
Threats to Auditor Independence: Evidence from Iran
}

\author{
By Ashkan Mirzay Fashami ", Pran Krishansing Boolaky \& \\ Kamil Omoteso ${ }^{ \pm}$
}

\begin{abstract}
This paper aims to examine threats to auditor independence in Iran. A mixed questionnaire, including both quantitative closed-ended questions and an openended qualitative question, is developed to investigate threats to auditor independence. Moreover, thematic analysis is used to triangulate the results against financial media articles throughout $1994-2014$. Findings suggest that while bribery, non-audit services, and economic condition are key threats to auditor independence in Iran, gifts and presents do not compromise independence given the Iranian culture. This study contributes to a better understanding of auditor independence in Iran, which may apply to other regional settings. Moreover, it provides some suggestions to improve the current Iranian Audit Organisation's auditor independence framework. (JEL M32)
\end{abstract}

Keywords: Audit, Auditor independence, Iran, Iran Audit Organisation, Threats to auditor independence.

\section{Introduction}

This paper aims to examine threats to auditor independence as identified in the research literature, and it triangulates these threats against the perceptions of professionals in Iran. Iran has experienced considerable business and accounting scandals over the past few decades that led to the gradual emergence of professional standards, including the audit profession (Rezaee \& Davani, 2013). Various events, such as the country's engagement in a war with Iraq have prevented the country from conducting audit research (Salehi, Mansouri, \& Pirayesh, 2008).

Extant Iranian audit literature is insufficient to determine threats to auditor independence. Salehi, Mansouri, and Azary (2009a) investigate the expectation gap in independence between investors and auditors. Their study suggests a major difference in their perceptions regarding independence. Investors consider internal factors (such as prospects of re-appointment) as severe threats to independence, whereas auditors consider external factors (such as regularity framework and corporate governance) as serious threats (Salehi et al., 2009a). Salehi (2011) suggests that the existence of an audit committee may improve independence. KarbasiYazdi and ChenariYukat (2012) suggest that a long-term relationship

\footnotetext{
"PhD Candidate, Griffith Business School, Griffith University, Brisbane, Australia.

•Senior Lecturer, Griffith Business School, Griffith University, Brisbane, Australia.

${ }^{ \pm}$Professor, PVC Dean, Derby Business School, University of Derby, UK.
} 
between auditors and their clients is a major threat to their independence (KarbasiYazdi \& ChenariYukat, 2012). Abdoli, Mahmoudzadeh, and Darvishan (2014) show that a mandatory auditor rotation safeguards independence, whereas Eshagniya and Salehi (2017) suggest that even restatement of financial statements of a client company does not lure to a change of its auditor.

This study has documented the Iran Statement of Membership No. 4 report of the International Federation of Accountants (IFAC) in 2009 and 2016. As per the report (www.ifac.org), the code of ethics development and implementation is still on an ongoing stage in Iran until 2017. The Iranian Institute of Certified Public Accountants has translated the IFAC code of ethics for professional accountants and is developing its ethical standards using Iranian laws, regulations, and other local factors. In 2014, The Iranian Audit Organisation (IAO) (also called The Audit Organisation), made changes to professional standards on independence to minimise the risk of auditor compromising independence and continues to exert its regulatory authority on compliance. Since then, there has been no investigation as to the effectiveness of this change. This study aims to provide insights on auditor independence in Iran by answering the following research questions:

What are the potential threats to auditor independence, and how should a regulator prioritise them to enhance auditor independence in Iran?

This study is motivated by four factors. Firstly, there is still a lack of empirical evidence in countries with specific settings like Iran. Iran is an Islamic jurisdiction predominated by Sharia's principles. It is also undergoing political tension(s) within and from outside the country. Beeman (2003) refers to the conflict between Iran and the U.S but much more as a cultural conflict of the postmodern feature. There is also a shortage of qualified accountants, and the government is still struggling to upgrade professional accountancy education to an international standard level. Given this situation, this study argues that there is as such no proper standard on independence that would satisfy not only the needs of the Iranian but also the international stakeholders.

Secondly, this study is also motivated by recent changes in professional standards related to auditor independence in Iran in a bid to increase our understanding of the similarities and differences compared to IFAC code of independence and other threats identified in the literature (Kosmala, 2007; Lee \& Stone, 1995; Ramazani \& Atani, 2010; Salehi \& Husini, 2011). This study is also driven by the mixed, if not, conflicting results in the literature on threats to independence in Iran (MohammadRezaei, Mohd-Saleh, Jaffar, \& Hassan, 2016; Salehi, 2009a, 2009b; Salehi et al., 2009a). As advanced by Salehi (2009a), there is yet no clear evidence on auditor independence in Iran.

Lastly, the research memo "Auditing Standards for clients Doing Business with Iran" of the Centre on Sanctions and Illicit Finance (CSIF) draws out attention on risks of auditors compromising independence in Iran. This CSIF discussion memorandum provides an assessment of the responsibilities of an external auditing firm whose clients are doing business with Iran. It covers auditing, disclosure, and reporting. This assessment explains the nature of responsibilities for an external auditing firm and the responsibilities for 
strengthening the overall control environment in which trade with Iran is carried out. This assessment is designed to create awareness of the nature of auditor's professional duties concerning Iranian businesses. CSIF's goal is to initiate public discussion, encourage regulatory support, and most importantly, to encourage leading accounting firms to adopt relevant audit practices voluntarily (Dubowitz, 2017).

CSIF identifies Iran as a highly risky business environment. CSIF found that companies doing business with Iran were corrupted and had to incur massive fines. For example, a French oil company, Total S.A., paid \$398 million in fines to U.S. authorities for paying for access to Iran's oil fields; a Norwegian firm paid a $\$ 3.5$ million fine to authorities for violating anti-bribery laws; and also been shown to have bribed Iranian officials for drilling rights. Iran ranks 130 out 168 for corruption by Transparency International, and $6 / 7$ on country risk by the Organisation for Economic Co-operation and Development. This study may contribute to the debate on auditor independence threats by providing insights on a country like Iran with its specificities in term of religion, culture, regulations, political tension, and efforts of the country to align if not harmonise with the international code of ethics on auditor independence.

Using a survey-based approach through questionnaires, including both closedended and open-ended question, this study empirically investigates perceptions of a sample of forty professionals on auditor independence in Iran. The findings suggest that bribery, non-audit services, and Iran's economic condition are primary threats to independence as opposed to gifts and presents. This finding suggests that gifts can be a business component without compromising auditor independence in Iran.

This paper contributes to the literature in several ways. First, it provides a better understanding of the audit profession in Iran, a non-IFRS country with an Islamic legal system. Due to created opportunities by Islamic laws and non-IFRS background of Iran, this paper provides a lens of observation to auditor independence issue in Iran and beyond. Given the similarities in Iran with other regional nations, the obtained evidence in this study can be instructive to other countries in the Middle East and beyond (Mirshekary \& Saudagaran, 2005). Second, given the current attention from the IAO to auditor independence issues, this paper provides an avenue for regulators and decision-makers to take preventive and corrective actions to safeguard auditor independence. Therefore, the capacity to prevent and detect fraud and error increases and financial statements may demonstrate a better picture regarding the financial affairs of companies. Precisely, as the IAO (2014a) recently identified 11 threats to auditor independence, this paper aligns with the IAO's Code through investigation and comparisons of different threats from the scholarly literature. Notably, not all threats in the literature align with the IAO's identified threats, so a variety of participants' perceptions in this paper suggests a lack of clarity regarding auditor independence issues in Iran. Third, this paper educates Iranian users of financial statements about audit profession, increasing their knowledge on how to protect themselves from financial loss. 
The rest of this paper is organised as follows. Section 2 provides the institutional background, outlining the legal and financial system of Iran. Section 3 reviews the related literature on auditor independence, whereas section 4 lays out the research design and method. Section 5 reports and interprets the findings, and the paper ends in section 6 with a concluding note.

\section{Institutional Background}

Baskerville, Wynn-Williams, Evans, and Gillett (2014, p. 307) state that: "Ethnicity is critical to a greater or lesser degree depending on the sociohistorical backdrop and the array of political systems." Ethnicity is a research continuum, beginning with nation-states as a unique culture and moving through to nations with multiple cultures (Baskerville et al., 2014). As such, each country's culture affects its legal system, which then affects its auditing practices (Ding, Jeanjean, \& Stolowy, 2005). Sharia constitutes the Iranian constitution (Wright, 2000) that is fundamental to its systems and practices.

\section{$\underline{\text { Religion and Auditing in Iran }}$}

This study proceeds on the basis that Iran, as a nation-state, is a monoculture, where Islamic laws dominate its banking and finance system (Ismail \& Tohirin, 2010; Rostami, Pakdel, Hasanzadeh Kojou, \& Hasanzadeh Kochou, 2016). Islamic revolutionists have supported the notion of a Sharia-based constitution throughout their Islamic movements before and after the Islamic Revolution in 1979 (Arjomand, 2002). Article 4 of the Iranian constitution mentions that Islamic standards (including ethical standards) must govern all laws of the country, and any law which is not based on Islamic principles is null (AoE, 1979). The Guardian Council of the Constitution is responsible for ensuring the consistency of the proposed laws to the constitution and Islamic laws (CIA, 2014).

Islamic principles shape audit practices (including auditor's code of ethics) of Islamic countries (Kasim, 2010). Sharia prohibits uncertainty, gambling, dealing with forbidden products (such as pornography or pork), monopoly, and misrepresentation (Black \& Sadiq, 2011). In an Islamic setting, auditors have to serve the needs of their nation in general, contrary to non-Islamic settings, where auditors are mainly and directly responsible to their shareholders (Ibrahim, Man, $\&$ Noor, 2013a), though they have a duty of care for the public interest. Based on Sharia's principles an auditor should investigate any possible changes in the product's ingredients or its production formulas (Khan, 1985) an aspect which is not covered in financial statements audit under the Anglo-Saxon principle. Auditors should also examine the extent to which an auditee has practised Israf, referring to the existence of extravagance and overspending in the auditee (Khan, 1985). Moreover, auditors should investigate the potential instances of Khiyanah, suggesting the existence of treachery, infidelity, or disloyalty and signs of any violation of trust regarding financial matters, honour, power, or position (Ibrahim et al., 2013a). Furthermore, they should determine whether the clients have practised Tatfif, i.e. treachery in weights and measures to other parties and their 
adherence to Sharia's injunction of Awful Mikyal Walmizan, referring to the accuracy of weights and measures of packed materials (Khan, 1985).

\section{$\underline{\text { Culture and Auditing in Iran }}$}

There is a link between national culture and auditing (Khlif, 2016). Prevailing cultural values affect auditors' judgements (Patel, Harrison, \& McKinnon, 2002). Power distance is one of the identified cultural dimensions by Lonner, Berry, and Hofstede (1980). Auditors in countries with a high level of power distance (e.g. Iran) are more likely to forgo their independence (Yamamura, Frakes, Sanders, \& Ahn, 1996). When managers practise autocratic leadership, they do not respect the opinions of their subordinates (Javidan \& Dastmalchian, 2003). They develop ideas and instruct their employees without considering their views (Javidan \& Dastmalchian, 2003). They are highly performance-oriented, though they are not future-oriented (Ding et al., 2005).

Individualism versus collectivism is another important factor (Lonner et al., 1980). Auditors from individualistic cultures better retain their ethical standards regardless of the applied pressure, whereas auditors from collectivist cultures may quickly succumb to their clients' pressure (McKinnon, 1984). Moreover, auditors from countries with a high level of uncertainty avoidance are more careful in their decision-making, and they do not merely focus on audit plans and rules (Hughes, Sander, Higgs, \& Cullinan, 2009). Iran is a country with a high level of power distance and a low degree of uncertainty avoidance and individualism (Bochner \& Hesketh, 1994). As such, it is likely that Iranian professionals, such as auditors, may be more likely to sacrifice their independence because it is less likely that they will be questioned (Hillmann, 1990).

\section{$\underline{\text { Iran Audit Organisation (IAO) }}$}

Iran Audit Organisation (IAO) is the primary regulator of the audit profession in Iran (Mirshekary \& Saudagaran, 2005). It was established by an act of the Iranian Parliament in 1987. It is affiliated to the Ministry of Economic Affairs and Finance. Its main objectives are to address the needs of government regarding audit and specialised financial services, to set accounting and audit standards in accordance with Sharia, and to fulfil the country's needs regarding accountancy. While considering the Iranian taxation rules and customs, it has modified the Iranian accounting standards based on international standards since 1997. The Accounting Standards Setting Committee of IAO produces the Iranian accounting standards. The committee has nine members. Five of them are from Board of Executive of IAO, two from Iranian Association of Certified Public Accountants, one from Security Exchange Agent Organisation, and one representative from industry (Chatterjee, Mirshekary, Al Farooque, \& Safari, 2010).

IAO introduced 33 audit guidelines in 1997, which after revision became standards in 1999. It revised some of them in later years (Gholamhossin \& Abdolhamid, 2012). The IAO codified and published a revised set of audit standards using the International Accounting Standards (IAS). It released a 
comparative table that compares the National Accounting Standards with IAS, and it introduced the national standards that are very similar to IAS (Mirshekary \& Saudagaran, 2005). Failure to comply with the principles and criteria for professional competence and care, non-compliance with the provisions of Code of Professional Conduct, and any behaviour against the professional affairs may lead IAO to consider some disciplinary actions (IAO, 2014a). The disciplinary actions can range from compulsory learnings; oral and written warnings; fines, restitution, and completing job through other members at the expense of offender; prevention from the independent professional activities; suspension of membership; to expulsion from the professional bodies for any non-compliance (IAO, 2014a).

\section{$\underline{\text { Iranian Capital Market Development and Auditing }}$}

Iran recognised the importance of the capital market during the 1930s (Mashayekhi \& Mashayekh, 2008). The Stock Exchange Act of the Parliament led to the formation of the Tehran Stock Exchange (TSE) in 1966. TSE officially started its operation on 4 February 1967. After the 1979 Islamic revolution, there were no national accounting standards in place, and many listed companies on TSE obtained a qualified audit report (Tabibi, 1993). In a bid to address this lacking, Iranian government established different audit enterprises such as Budget, Planning, and National Industries Organisation to manage its governmental entities (Moghaddam, Shadmehr, Mousavian, \& Minab, 2012). Moreover, the Act of using expert and professional services of certified accountants as official accountants of the Parliament led to the formation of the Society of Certified Accountants of Iran in 1993 (Moghaddam et al., 2012).

Figure 1. Structure of the Iranian Capital Market.

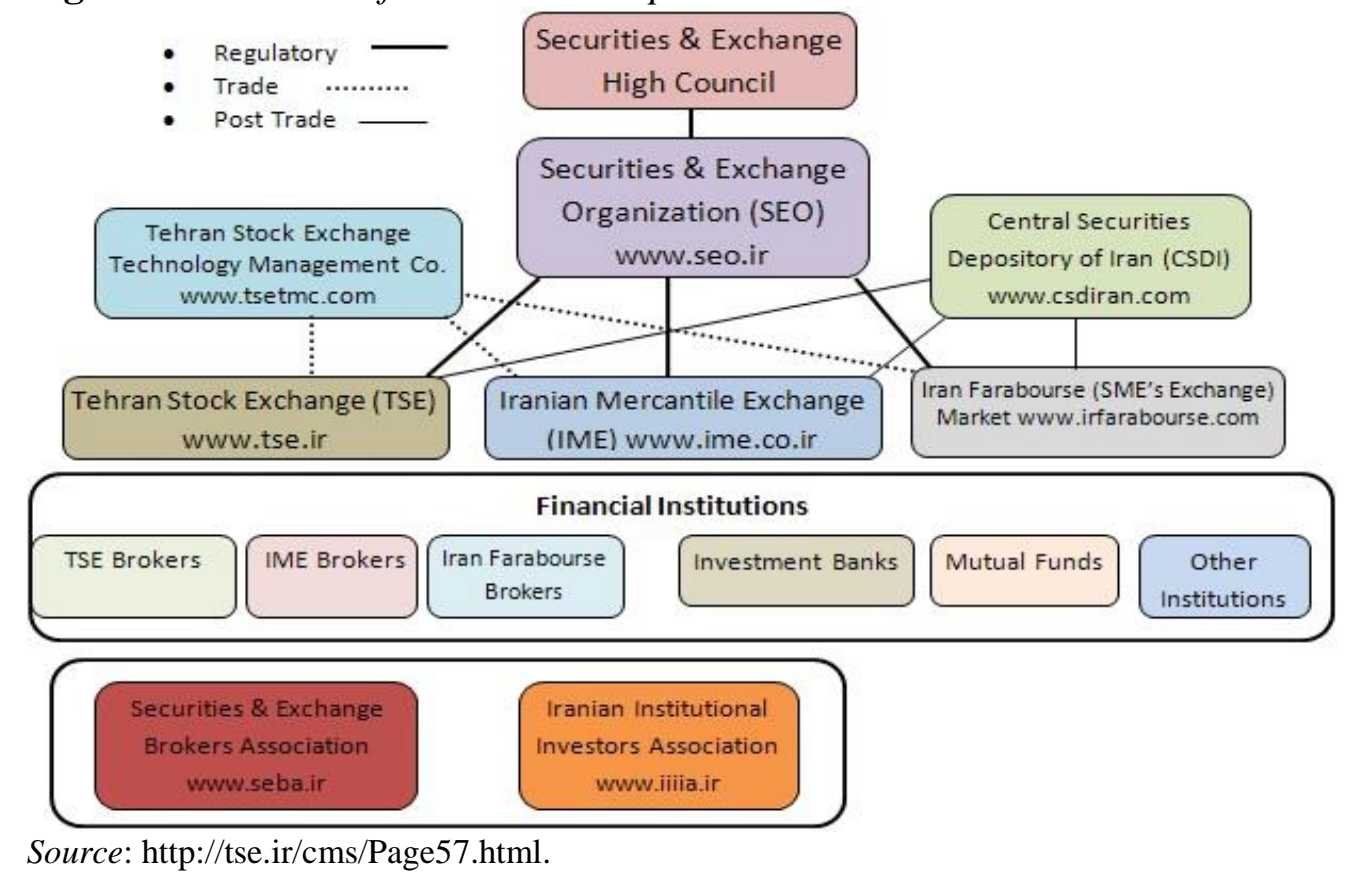


TSE joined the Federation of Euro-Asian Stock Exchanges in 1995 (TSE, 2006). Moreover, it permitted listed companies to issue corporate bonds in 2003 (TSE, 2006). The new Securities Act enabled the Securities and Exchange Organisation and Securities and Exchange High Council to govern the Iranian capital market in 2005 (TSE, 2005). Iranian government established the National Development Fund based on Article 84 of its Fifth Five-year Socio-Economic Development Plan (2011-2015) in 2011 to use its oil revenues for its future investments (Fashtami, 2014). Figure 1 depicts the Iranian capital market.

$\underline{\text { International and Iranian Ethical Standards for Professional Accountants }}$

According to the International Ethics Standards Board for Accountants threats to auditor independence are grouped into five categories (IFAC, 2013), contrary to IAO where they are listed in eleven different situations (IAO, 2014b). Table 1 shows the equivalence of the IAO's list of independence threats with the categories of threats to independence as per the International Ethics Standards Board for Accountants.

Table 1. Equivalence Table: IAO and IFAC - Threats to Auditor Independence

\begin{tabular}{|l|c|}
\hline IAO & IFAC \\
\hline $\begin{array}{l}\text { Family, personal, or financial relationship between auditors } \\
\text { and their clients }\end{array}$ & $\mathrm{a} \& \mathrm{~d}$ \\
\hline $\begin{array}{l}\text { Inclusion of auditors in their clients' board of directors, senior } \\
\text { officers, or partners }\end{array}$ & $\mathrm{b} \& \mathrm{c}$ \\
\hline Provision of non-audit services to clients & $\mathrm{a}$ \\
\hline High management pressure on auditors & $\mathrm{e}$ \\
\hline High audit fees & $\mathrm{a}$ \\
\hline Existence of contingent fees & $\mathrm{a} \& \mathrm{e}$ \\
\hline Purchasing and accepting gifts and hospitality & $\mathrm{a} \& \mathrm{~d}$ \\
\hline Ownership of audit firms by those other than auditors & $\mathrm{e}$ \\
\hline Presence of former audit partners as clients & $\mathrm{b} \& \mathrm{~d}$ \\
\hline Existence of lawsuits between auditors and their clients & $\mathrm{c} \mathrm{\&} \mathrm{e}$ \\
\hline Long-term association between auditors and their clients & $\mathrm{a}, \mathrm{b}, \& \mathrm{~d}$ \\
\hline
\end{tabular}

Note: $\mathrm{a}=$ self-interest threat, $\mathrm{b}=$ self-review threat, $\mathrm{c}=$ advocacy threat, $\mathrm{d}=$ familiarity threat, and $\mathrm{e}=$ intimidation threat.

A review of past studies on audit independence in the Iranian literature reveals gifts and presents, bribery, audit partner tenure, prospects of reappointment, nonexistence of an audit committee, and auditors' lack of competence as threats to independence (Abdoli et al., 2014; Dehghan, 2013; Salehi, 2009a, 2011; Salehi \& Husini, 2011; Salehi et al., 2009a). Table 2 provides a comparison between identified threats in IFRS countries, Iran, and the international threat framework. The reason(s) for including IFRS countries is that they are more likely to adopt IFAC ethical standards. 
Table 2. Threats to Auditor Independence: IFRS Countries, Iran, and International Threat Framework

\begin{tabular}{|c|c|c|c|c|c|}
\hline $\begin{array}{l}\text { IFRS } \\
\text { countries }\end{array}$ & Reference & $\begin{array}{l}\text { Equivalence } \\
\text { to the } \\
\text { international } \\
\text { threat } \\
\text { framework }\end{array}$ & Iran & Reference & $\begin{array}{c}\text { Equivalence to } \\
\text { the international } \\
\text { threat } \\
\text { framework }\end{array}$ \\
\hline $\begin{array}{l}\text { Receiving } \\
\text { gifts and } \\
\text { presents }\end{array}$ & $\begin{array}{l}\text { Du (2018), } \\
\text { Fern (1985) }\end{array}$ & $a \& d$ & $\begin{array}{l}\text { Receiving } \\
\text { gifts and } \\
\text { presents }\end{array}$ & $\begin{array}{c}\text { Salehi } \\
\text { (2009a), } \\
\text { Salehi et al. } \\
\text { (2009a) }\end{array}$ & $a \& d$ \\
\hline Bribery & $\begin{array}{c}\text { Kosmala } \\
(2007)\end{array}$ & $\mathrm{a}$ & Bribery & $\begin{array}{c}\text { Dehghan } \\
\text { (2013), } \\
\text { Ramazani } \\
\text { and Atani } \\
\text { (2010) }\end{array}$ & A \\
\hline $\begin{array}{l}\text { Audit } \\
\text { partner } \\
\text { tenure }\end{array}$ & $\begin{array}{c}\text { Ye, Carson, } \\
\text { and Simnett } \\
\quad(2006)\end{array}$ & $\mathrm{a}, \mathrm{b}, \& \mathrm{~d}$ & $\begin{array}{c}\text { Audit partner } \\
\text { tenure }\end{array}$ & $\begin{array}{c}\text { Abdoli et } \\
\text { al. (2014), } \\
\text { Salehi and } \\
\text { Kangarlouei } \\
\text { (2010) }\end{array}$ & $\mathrm{a}, \mathrm{b}, \& \mathrm{~d}$ \\
\hline & & & $\begin{array}{l}\text { Prospects of } \\
\text { reappointment }\end{array}$ & $\begin{array}{l}\text { Salehi et al. } \\
(2009 a)\end{array}$ & $a \& b$ \\
\hline $\begin{array}{l}\text { Non- } \\
\text { existence } \\
\text { of an audit } \\
\text { committee }\end{array}$ & $\begin{array}{c}\text { Gul (1989), } \\
\text { Nur } \\
\text { Barizah } \\
\text { Abu, Abdul } \\
\text { Rahim } \\
\text { Abdul, and } \\
\text { Hafiz Majdi } \\
\text { Abdul } \\
\text { (2005), } \\
\text { Teoh and } \\
\text { Lim (1996) }\end{array}$ & $\mathrm{a}, \mathrm{c}, \& \mathrm{~d}$ & $\begin{array}{l}\text { Non-existence } \\
\text { of an audit } \\
\text { committee }\end{array}$ & $\begin{array}{c}\text { Salehi } \\
(2009 a, \\
2011)\end{array}$ & $\mathrm{a}, \mathrm{c}, \& \mathrm{~d}$ \\
\hline $\begin{array}{l}\text { Auditors' } \\
\text { lack of } \\
\text { competence }\end{array}$ & $\begin{array}{l}\text { Lee and } \\
\text { Stone } \\
(1995)\end{array}$ & $\mathrm{a} \& \mathrm{e}$ & $\begin{array}{c}\text { Auditors' lack } \\
\text { of } \\
\text { competence }\end{array}$ & $\begin{array}{l}\text { Mansouri, } \\
\text { Pirayesh, } \\
\text { and Salehi } \\
(2009), \\
\text { Salehi and } \\
\text { Husini } \\
(2011)\end{array}$ & $\mathrm{a} \& \mathrm{e}$ \\
\hline
\end{tabular}

Note: $\mathrm{a}=$ self-interest threat, $\mathrm{b}=$ self-review threat, $\mathrm{c}=$ advocacy threat, $\mathrm{d}=$ familiarity threat, and $\mathrm{e}=$ intimidation threat.

There are differences between IFRS countries and Iran regarding auditors' legal liabilities (Rostami et al., 2016). In an IFRS country, auditors may lose their licence if they fail to maintain their independence (Beattie, Brandt, \& Fearnley, 1999). However, audit firms that breach the regulations of Iranian Association of Certified Public Accountants may face one of the two potential consequences. First, they may incur a penalty from the quality control committee of the 
Association (which would not be severe) (Azizkhani, Shailer, \& Monroe, 2012). Second, they may lose their licence after an assessment of the peer review audit committee of Securities and Exchange Organisation (which would be rare) (Azizkhani et al., 2012). Given that Iranian law does not consider any civil action against audit firms to recover damages, the risk of litigation is low. As a result, auditors may have more rooms to compromise their independence (Azizkhani et al., 2012).

\section{Literature Review}

\section{Auditor Independence: A Global Overview}

Auditor independence is the cornerstone of the audit profession ( $\mathrm{Du}, 2018$; Franzel, 2012). Prior research suggests that accounting scandals trigger reforms and new regulations for the profession (Bhasin, 2013; Hilary \& Lennox, 2005; Kozloski, Meckfessel, Moehrle, \& Williams, 2016; Pai \& Tolleson, 2015). In consequence, some have developed their ethical standards, whereas others have fully adopted the IFAC code of ethics (Branson, Chen, \& Anderson, 2015). As for now, more than 130 countries have adopted IFAC ethical standards (IFAC, 2018). However, the question of whether it is possible to regulate or mandate auditor independence attracts much attention in mature capital markets such as the United States, the United Kingdom, and Australia (Stevenson, 2002; Umar \& Anandarajan, 2004).

Regulatory approaches inevitably seek to mandate auditor independence (DeFond, Raghunandan, \& Subramanyam, 2002; Watts \& Zimmerman, 1983). For example, they make proposals to prohibit particular conflict of interest situations (Moore, Tetlock, Tanlu, \& Bazerman, 2006), including provisions of non-audit services (Craswell, 1999), or impose requirements regarding audit partner rotation (Carey \& Simnett, 2006b).

\section{Non-audit Services}

International Code of Ethics for Professional Accountants mentions that the provision of non-audit services may result in self-review, self-interest, and advocacy threats (IFAC, 2014a). The Code instructs auditors to evaluate potential threats of non-audit services before any engagement. The auditors should preclude to provide any non-audit services if they are unable to reduce independence threats to an acceptable level (IFAC, 2014a). Non-audit services can compromise auditor independence for two reasons: First, they increase auditors' financial dependency on their clients, reducing their desire to disagree with their clients' requirements. A high amount of non-audit services creates significant revenues for auditors, making it more harmful to lose their clients. High non-audit fees outweigh potential costs of non-audit services (litigation risk and reputation loss), making it worthy to compromise auditor independence (DeFond et al., 2002). Second, managerial role resulted from consultancy nature of non-audit services brings bias 
into auditors' judgement, endangering their independence (SEC, 2000). Consultancy services provide private information for auditors, generating them economic rent by decreasing audit costs (Campa \& Donnelly, 2016).

Non-audit services are highly associated with independence in appearance. They signal a lack of independence, reducing users' trust in financial statements (Beck, Frecka, \& Solomon, 1988b). They increase the likelihood of a selfselection bias (Abdel-Khalik, 1990). Independent auditors are more likely to lose their job as a consequence of their disputes with their clients (Simunic, 1984). High non-audit services impair independence, reducing auditors' desire to dispute with their clients. This increases auditors' tenure with their clients (Beck, Frecka, \& Solomon, 1988a). It reduces the likelihood of a qualified audit opinion's issuance. It encourages auditors to maintain their relationship with their clients to continue receiving their income, regardless of potential harms to their independence (Hay, Knechel, \& Li, 2006a). However, Iranian literature does not consider non-audit services as threats to auditor independence. This suggests differences between Iranian and international audit environments, motivating this study to identify independence threats in Iran.

\section{Audit Firm \& Audit Partner Tenure}

Audit firm tenure refers to the length of time an audit firm works for a client, whereas audit partner tenure refers to the length of time a partner of the audit firm conducts the audits of its client (Chen, Lin, \& Lin, 2008). Many countries such as Argentina, Australia, Belgium, China, Denmark, France, Germany, Hong Kong, Mexico, Netherlands, New Zealand, Norway, Russia, Taiwan, the UK, and the U.S. limit their audit partner tenure (Lennox, Wu, \& Zhang, 2014). For example, the U.S. and the UK require audit partner rotation and a cooling-off period of every five years (APB, 2009; SEC, 2002, 2003). Moreover, China requires audit partner rotation of every five years with a two-year cooling-off period (Lennox et al., 2014), whereas Taiwan requires rotation of every five years with no coolingoff period (Chi, Huang, Liao, \& Xie, 2009). However, they do not require mandatory rotation of audit firms (Lennox et al., 2014).

Nevertheless, six countries (Brazil, India, Italy, Singapore, South Korea, and Turkey) have a legal requirement to rotate their audit firms after a maximum specified period (Bleibtreu \& Stefani, 2013; Liang, 2015). For example, South Korea has mandated audit firm rotation every seven years since 2006 (Kwon, Lim, \& Simnett, 2010). Moreover, the European Union has recently mandated rotation of audit firms (European Parliament, 2014). The Australian Securities and Investment Commission's Chairman mentions that they have noticed a $30 \%$ rise in audit failures of listed companies in 2012 (Durkin \& King, 2012). The Chairman warns that a mandatory audit firm rotation would be proposed to the Australian government if they detect any further rise in audit failures (Jenkins \& Vermeer, 2013). 


\section{Audit Partner Tenure: Pros \& Cons}

International Code of Ethics for Professional Accountants mentions that a long-term relationship between auditors and their clients may lead to familiarity and self-interest threats (IFAC, 2014a). The Code mentions that an auditor should not remain a key partner of a company for more than seven years. The auditor should not participate in audit-related activities, provide consultation services, or influence outcomes of engagement for a minimum period of two years after completion of its seven years engagement period (IFAC, 2014a). Similarly, term 21.17 of the Iran Audit Organisation's Code of Professional Conduct mentions that a long-term relationship between auditors and their clients may threaten auditor independence. In such circumstances, auditors shall take the necessary measures to safeguard their independence (IAO, 2014a). Paragraph 2 of clause 10 of Tehran Stock Exchange requirements obliges all public listed companies to rotate their audit partners every four years (Abdoli et al., 2014). This requirement does not permit the listed companies to reassign their former audit partners in future (Abdoli et al., 2014).

A long-term relationship encourages auditors to readily accept their auditee's accounting and reporting choices (Chen et al., 2008). A long-term tenure creates a personal relationship between auditors and their clients (Chen et al., 2008). It compromises auditors' objectivity because direct and indirect management's pressures affect their attitude over time (Carey \& Simnett, 2006a). Auditors' bias influences their behaviour during the audit and reporting process, wherein in case of a conflict of interest auditors favour their clients (Dopuch, King, \& Schwartz, 2003). A long-term tenure increases familiarity threat, limiting the number of effective audit-testing methods. It routines an audit plan, reducing auditors' desire to use creativity in their audit procedures (Arrunada \& Paz-Ares, 1997). Moreover, it reduces auditors' desire to issue a qualified audit opinion, reducing the quality of their services (DeFond et al., 2002).

However, a long-term relationship between auditors and their clients can also be beneficial, as it increases auditors' knowledge regarding their clients' operations and systems (Petty \& Cuganesan, 1996). Auditors should conduct various substandard audits on their new clients to gain enough knowledge regarding their operation (Berton, 1991). They may not detect irregularities during their initial engagement years because of their lack of familiarity, reducing audit quality (Petty \& Cuganesan, 1996). Auditors do not have sufficient knowledge to establish relevant quality controls to detect irregularities in initial stages. They need to have enough time to familiarise themselves with their clients' audit methodology and databases (Carey \& Simnett, 2006a). Moreover, they face a higher litigation risk in the initial stages of their audit because of their lack of knowledge about their clients' specific risks (Palmrose, 1989).

Client-specific knowledge is essential for auditors' work, though other types of knowledge such as general and industry knowledge help auditors to complete their tasks (Knapp, 1991). Auditors may not detect material misstatements during the initial years of their engagements, due to their lack of client-specific knowledge (Beck et al., 1988b). Lack of client-specific knowledge may cause 
auditors to readily accept their clients' explanations (Kinney $\mathrm{Jr} \&$ McDaniel, 1996). Auditors' extra efforts cannot mitigate their lack of knowledge about their client-specific threats. Therefore, the likelihood of fraudulent financial reporting is higher during the initial years of engagement (Carcello \& Nagy, 2004). However, long-term tenure leads to less extreme income-increasing and income-decreasing accruals, restricting earnings management (Myers, Myers, \& Omer, 2003).

\section{The Scope of Audit Report According to Sharia}

Islam has banned any risky or hazardous sale because it may lead to an argument among the related parties (Khan, 2011). Based on Sharia, auditors should report particular transactions. For example, they should determine whether a client has engaged in the sale of al-gharar, meaning the sale of a product which is not present, or its consequence is unknown (Ibrahim, Man, \& Noor, 2013b). Moreover, they should discover the extent to which a client has practised Israf, meaning the existence of extravagance in an auditee. The governments determine the adequate level of expenditures, helping auditors to discover Israf (Khan, 1985). Furthermore, auditors should report to what extent their clients have practised Bakhs, meaning voluntary attempts to reduce the value of a product before its sale. Thus, auditors should investigate any possible change in a product's ingredients or its production formulas (Khan, 1985). Further, they should investigate potential instances of Khiyanah, meaning the existence of treachery, infidelity, or disloyalty. They should look for signals of any violation of trust regarding financial matters, honour, power, or position (Ibrahim et al., 2013b).

Based on Sharia, auditors should determine any Tatfif practised by their clients, meaning harms in weights and measures caused to other parties. They should measure their client's adherence to Sharia's injunction of Awful Mikyal Walmizan, meaning the accuracy of weights and measures of packed materials (Khan, 1985). Moreover, auditors should investigate their auditee's compliance with Uqud, meaning the fulfilment of its contracts. They should search for the areas where an auditee has failed to meet its contractual obligations and report them (Khan, 1985). Furthermore, they should determine if there is any indication of dishonesty, fraud, or deceit in an auditee. They should consider a broad range, from embezzlement and misappropriation to trade secrets or intellectual property to conflict of interest or commitment (Ibrahim et al., 2013b). Khan (2011) states that falsehood damages producers, traders, and customers. Auditors should determine the existence of any falsehood or breach of pact or promise in their client's organisation and report them (Ibrahim et al., 2013b).

\section{Audit-related studies in Iran}

Existing audit-related literature is insufficient to understand the audit market and auditor independence in Iran. Expectation gap between auditors and investors is investigated by Salehi, Mansoury, and Azary (2009b). The results suggest that there is a major difference between auditors and investors' perception regarding the actual level of auditor independence. Investors consider internal factors (i.e. 
prospects of reappointment) as serious threats, whereas auditors consider external factors (i.e. regularity framework and corporate governance) as serious threats to independence. There is a significant difference between auditors and investors' perceptions of gifts and presents. Perceptions regarding prospects of reappointment are considerably different too (Salehi et al., 2009b). Salehi et al. (2009b) suggest at least some common grounds in perceptions between auditors and investors regarding the expected level of auditor independence, albeit at different levels. Both groups consider gifts and presents and prospects of reappointment as threats to auditor independence (Salehi et al., 2009b).

The effects of a long-term relationship between auditors and their clients on auditor independence are investigated by KarbasiYazdi and ChenariYukat (2012). Their study finds this relationship a major threat to independence. The long-term relationship encourages auditors to incorporate their clients' requests, preventing them from working objectively. In contrast, a mandatory rotation increases auditors' resistance against management pressure (KarbasiYazdi \& ChenariYukat, 2012). The effects of two influential factors (audit firm size and auditor's report) in audit partner rotation's decisions are investigated by Abdoli et al. (2014) in another Iranian study. Their study shows that concerned factors do not affect rotation decisions. Their study emphasises on the importance of rotation to maintain auditor independence.

Prior research regarding audit committees of Iranian companies emphasises on their role. For example, Salehi and Abedini (2008) find that the existence of an audit committee improves auditor independence. Salehi and Azary (2008) suggest that audit committees ensure the objectivity of financial reporting. Salehi and Nanjegowda (2006) find that audit committees contribute to decision makings regarding auditors' selection, retention, and dismissal. Although the importance of audit committees is acknowledged by prior studies, they do not play an important role in Iranian companies (Salehi, 2011). The barriers to an effective audit committee are investigated by Salehi (2011). Salehi finds that individualism among Iranian audit practitioners, centralisation trend of Iranian managers, and lack of an effective legal force are major causes of audit committees' ineffectiveness (Salehi, 2011).

\section{$\underline{\text { Auditor Independence in Iran }}$}

\section{Gifts and Presents}

Social networking is an essential part of modern businesses (Taormina \& KinMei Lao, 2007). Business people may be unable to pursue their objectives alone and use gifts to achieve them (Law, 2010). Gifts and presents are acceptable in some business cultures, such as Chinese (Hwang \& Staley, 2005). They are a sign of respect in China (Levy, 1995). Similarly, Iran has deeply embedded traditions regarding gifts. The former king of Iran, Fath Ali Shah, sent his portraits abroad as gifts to show Persian royal power (Anonymous, 2011). Another king, Shah Muhammad Khudabanda, sent 34 camels piled high with treasure to the former Turkish king, Ottoman Sultan Selim II, as a sign of respect in 1567. Large animals 
such as horses and elephants were used to express respect, the award rendered services, or celebrate annual events like the New Year throughout the $16^{\text {th }}$ and $17^{\text {th }}$ century (Ybarra, 2011). Formal gifts are widely accepted in Iran. Some occasions require particular gifts. These gifts merely symbolise existing relationships (Betteridge, 1985).

However, according to term 21.13 of Iran Audit Organisation's Code of Professional Conduct purchase of goods or services with specific conditions, acceptance of irrelevant gifts, and receiving more than a reasonable amount of gifts are serious threats to auditor independence. Term 15.2.E states that auditors must refrain from accepting or giving gifts that may reasonably lead to a belief that their professional judgement or those who deal with them is affected. Unusual gifts can vary based on the circumstances. However, overall, auditors shall abstain from being placed in situations that damage their professional reputation (IAO, 2014a).

Gifts may result in illegal payments, corruption, and bribery (Snell, 1999). They increase the likelihood of violating laws, auditing standards, and codes of professional conduct (Hwang \& Staley, 2005). They lead to hidden trades, power dependence, and bureaucratic privileges (Fan, 2002). Gifts damage fiduciary duties of auditors, benefiting them at others' costs (Dunfee \& Warren, 2001). Prior research suggests that offering presents affect perceived independence, wherein even small gifts are threats to independence (Du, 2018; Fern, 1985; Pany \& Reckers, 1980). Moreover, gifts lead to a bias in auditors' decisions and prevent them from precisely checking areas of concern (Fern, 1985). They negatively affect auditors' judgments in a conflict of interest situation, leading to unethical behaviours (Au \& Wong, 2000). Ethical auditors actively avoid any unethical behaviour, including the acceptance of gifts (Fern, 1985). They exercise their duties while preventing any potential threat to their independence (Au \& Wong, 2000).

\section{Bribery}

Bribery is to encourage someone to do something illegal or influence its sense of justice, due process, and discretion in favour of the giver through provision or promise of something instead (Arowosaiye, 2008). It is a significant threat for today's business, remaining a primary concern for various organisations. It may happen in any department at any level. It affects the overall effectiveness of a market on top of its processes and individuals. Bribers prioritise their interests over others, damaging trust between business partners and destabilising lawfulness of social institutions (Turow, 1985). The public in any country do not accept bribery and request their authorities to combat against fraud.

Article 49 of the Iranian Constitution (Confiscation) mentions that the government is responsible for confiscating all wealth accumulated through bribery and restoring it to its legitimate owner. If no owner can be identified, the wealth must be entrusted to the public treasury (Assembly of Experts, 1979). This rule must be executed by the government with due care, after investigation and provision of necessary evidence under Islamic laws (Assembly of Experts, 1979). 
Moreover, term 6 of the Iranian Institute of Certified Accountants' Code of Professional Conduct mentions that as moral characteristics of auditors are the most important part of their profession, the audit principles should satisfy them (IICA, 1985).

Bribery affects auditors' role for several reasons. First, it encourages auditors to increase their efforts or fees to prevent potential future litigations or reputation losses (Simunic, 1984). Second, it lessens the credibility of faulty companies, reducing their share values (Smith, Stettler, \& Beedles, 1984). It leads to price and volume variability (Lyon \& Maher, 2005). Third, management's turnover as a consequence of loss of reputation, costs of avoiding any potential investment in highly corrupted settings, costs to build an adequate internal control infrastructure to deter bribery, and costs of hiring external bodies to investigate fraud are additional costs associated with bribery (Lyon \& Maher, 2005).

\section{Audit Partner Tenure}

A long-term tenure creates a certain level of confidence regarding auditees' financial statements, reducing auditors' desire to check financial reports effectively (Shockley, 1981). The likelihood that auditors issue a going-concern opinion for a client that is close to insolvency increases, as their relationship period increases (Geiger \& Raghunandan, 2002). Similarly, Copley and Doucet (1993) suggest a negative association between audit partner tenure and audit quality. A long-term relationship increases auditors' reliance on internal audit reports, discouraging them from using rigorous audit procedures (Arrunada \& Paz-Ares, 1997). Auditors may tend to predict the outcomes before the conduct of an audit, reducing the likelihood of discovering mistakes and errors (Arrunada \& Paz-Ares, 1997). Limitation of auditors' future income because of a mandatory rotation helps them to maintain their audit quality throughout their auditors' engagement period (Johnson, Khurana, \& Reynolds, 2002).

A prolonged tenure discourages audit firms to compete against each other (Carrera, Gómez-Aguilar, Humphrey, \& Ruiz-Barbadillo, 2007). Moreover, it limits the scope of auditors, preventing them from becoming familiar with other industries. Auditors do not attempt to update their knowledge and skill to respond to current requirements of their audit market, reducing the likelihood of the audit market improvement (Carrera et al., 2007). Therefore, audit quality declines and potential investors lose their confidence in the market (Craswell, Stokes, \& Laughton, 2002). Ye et al. (2006) find that audit partner tenure is the most critical threat to auditor independence. Similarly, Copley and Doucet (1993) show a negative relationship between audit partner tenure and audit quality in government audits.

\section{Prospects of Reappointment}

The term 8.7 of Iranian Institute of Certified Accountants' Code of Professional Conduct states that an auditor shall not accept another auditor's work unless the other auditor's right to practice is officially revoked or professional 
reasons regarding non-acceptance of a job by the other auditor are not mentioned. The auditor shall request the name of the former auditor from their client company in writing upon receipt of a new job offer and in case the former auditor is confirmed or with permission of client company contact the former auditor via registered post and investigate any likely professional reasons. In case of the existence of professional reasons or refusal of the client company to permit to contact, the auditor is banned from accepting the job offer (IICA, 1985).

A desire for reappointment influences audit firms' behaviours, wherein they may sacrifice their loss of reputation and litigation risks to continue receiving their audit fees (Raghunathan, Lewis, \& Evans III, 1994). Expected future fees increase auditors' dependency on their clients (Gietzmann \& Sen, 2002). They may have a greater tendency to collude with their auditees to maintain their position (Gietzmann \& Sen, 2002). They may surrender to their clients' desire to obtain non-audit services in their next engagement (Raghunathan et al., 1994). Moreover, a desire for reappointment may encourage auditors to engage in low-balling to offset their initial loss by gaining in subsequent periods (Simon \& Francis, 1988).

Some companies voluntarily permit their shareholders to vote regarding their auditors' reappointment (Krishnan \& Ye, 2005). Shareholders are often more dissatisfied with their auditors than what their votes suggest (Sainty, Taylor, \& Williams, 2002). Auditors' desire to succumb to their clients' aggressive accounting techniques decreases as outside investors exercise control over their selection (Moore et al., 2006). Some factors may affect shareholders' votes regarding their auditors' reappointment. For example, auditors that have a longterm tenure (Dao, Mishra, \& Raghunandan, 2008), provide non-audit services (Raghunandan, 2003), and issue a going-concern opinion (Sainty et al., 2002) are more likely to receive a negative vote from their shareholders.

\section{Non-existence of an Audit Committee}

TSE's requirements state that the purpose of audit committees' formation is to help boards of directors regarding their supervisory responsibility to obtain reasonable confidence regarding effectiveness of governance processes, risk management, and internal controls; financial reporting health; internal audits effectiveness; independent auditors independence and independent audits effectiveness; and observance of rules, provisions, and requirements (TSE, 2013).

Prior research suggests that an audit committee plays an essential role in safeguarding auditor independence (Gold, Klynsmit, Wallage, \& Wright, 2014; He, Pittman, Rui, \& Wu, 2017; Nur Barizah Abu et al., 2005; Soliman \& Ragab, 2014). For example, Nur Barizah Abu et al. (2005) examine factors that may influence auditor independence from commercial loan officers' perspectives in Malaysian-owned commercial banks. They find that the non-existence of an audit committee poses a threat to objectivity (Nur Barizah Abu et al., 2005). An audit committee's principal duty is to monitor the financial reporting processes of its company (Nelson, Elliott, \& Tarpley, 2000). Committee members frequently meet with external auditors and financial managers to monitor financial statements, audit processes, and internal accounting controls of the company (Nelson et al., 
2000). Their expertise reduces the likelihood of financial restatements because they better understand the internal audit system and governance structure of their company (Raghunandan, Rama, \& Read, 2001).

An audit committee works as an arbiter between a company's management and its audit firm to create a fair and precise report (Klein, 2002). It may intervene on different matters, such as management judgements, accounting estimates and audit adjustments, disagreements between management and auditors, and transactions between the company and its officers or employees (Klein, 2002). It frequently meets with financial managers and auditors to monitor its company's audit process (Carcello \& Neal, 2003). It may prevent an auditor's dismissal in case of a disagreement with management (Carcello \& Neal, 2003). An independent audit committee encourages auditors to prioritise the interests of shareholders and express the realities (Levine \& Kornish, 2000). Independent members reduce the necessity of a legal intervention to protect shareholders (Levine \& Kornish, 2000). However, prior social and professional ties such as prior employment between audit committee members and management increase management's ability to influence the committee's decisions (Westphal \& Stern, 2006).

\section{Auditors ' Lack of Competence}

The term 11.C of Iran Audit Organisation's Code of Professional Conduct states that auditors shall perform their duties with accuracy, competence, and perseverance. They shall consistently maintain their professional knowledge and skill at a level, wherein confidence can be obtained that their services are acceptable and offered according to the latest developments in profession, rules, and regulations (IAO, 2014a). The term 22 states that auditors shall refrain from accepting the professional services that they do not have the competence to perform. The term allows auditors to use expert services while accepting a job if they need them to perform some of their professional services (IAO, 2014a).

Competence and independence are two mutually inclusive characteristics of an audit, wherein independence is unachievable unless auditors have the required competence (Barnes \& Huan, 1993). Lee and Stone (1995) investigate the relation between auditor competence and independence. Their findings suggest that assuming no other conflicting interests, a greater probability of competence leads to a higher chance of independence (Lee \& Stone, 1995). Alternatively, assuming no other conflicting interests, a greater probability of incompetence results in a higher likelihood of dependence (Lee \& Stone, 1995). Lee and Stone find competence as a prerequisite for independence. That is, independence is possible if an auditor is competent and able to satisfactorily complete the designated audit tasks (Lee \& Stone, 1995).

Auditors should have enough training and knowledge regarding legal and contractual terms and also the ability to apply professional reasoning. Auditors' proficiency reduces audit risk, as sufficient knowledge about a client company and its environment helps auditors in their client's acceptance decisions (Hayes \& Schilder, 2005). Technical knowledge of auditors enables them to detect a company's aggressive accounting practices, providing an opportunity to provide 
their reports reasonably (Beattie, Fearnley, \& Brandt, 2004). Auditors' competency enables them to identify misleading prospectuses, protecting the potential investors' funds. Moreover, it helps auditors to evaluate the management control systems and their cost policies (Hayes \& Schilder, 2005).

Competent auditors can detect and prevent fraud (Hayes \& Schilder, 2005). Moreover, they can assess a company's success to achieve its goals (Johnsen, Robertsen, \& Äsland, 2004). They can respond to complex situations, enabling them to produce a credible audit report without any reliance on internal reports (Mironiuc, Chersan, \& Robu, 2013). Auditors often rely on prior year's risk assessments to plan a new assessment, wherein difficult tasks encourage more reliance on prior works (Monroe \& Ng, 2000). Auditors' incompetence increases the likelihood of a failure, because prior years' results may not apply to the current year. Incompetent auditors do not critically evaluate outcomes of risk assessments because of their lack of understanding regarding them (Bagranoff \& Vendrzyk, 2000).

\section{Research Design}

This study uses a questionnaire survey-based to conduct this research similar to past studies on related topics (Singh, 2008). Prior Iranian audit-related studies use questionnaires to collect data from their participants (Abdoli et al., 2014; Saeidi, 2012; Salehi, 2011; Salehi \& Husini, 2011; Salehi et al., 2009a). In order to assist in quantifying the responses from the survey, this study has used a five-level Likert scale to examine the six identified threats (as discussed in Section 3) to auditor independence. Because close-ended questions cannot capture all responses, this study has further used an open-ended question to allow participants to nominate other threats (Abdoli et al., 2014; Saeidi, 2012; Salehi, 2011; Salehi \& Husini, 2011).

\section{Questionnaire}

\section{$\underline{\text { Structure and Contents }}$}

The questionnaire is divided into three sections. Section I: Demographic information, Section II: Experience and perception regarding threats to auditor independence, and Section III: Additional comments on threats to auditor independence in Iran. The first section contains five questions and asks participants to discuss their demographic information. The second part contains five questions and requires participants to rank the importance of the six identified threats from the previous literature based on their experience and opinion about them. The last section, in an open-ended question, asks participants to nominate other threats to auditor independence in Iran based on their personal views. A copy of the questionnaire is given in Appendix 1. 


\section{$\underline{\text { Administration }}$}

A pilot study was conducted on two accounting academics and an academic ethical adviser to assess the understandability and simplicity of the questions in the questionnaire. The questionnaire was then revised according to their suggestions. As participants had to answer some questions regarding their professional life experience, they may have felt more comfortable with a self-administered questionnaire than other methods that require direct contact with a researcher. The self-administered questionnaire ensured their privacy and provided them with sufficient time to analyse the questions and provide their desired responses (Gregg, 2008). It prevented the researcher's influence over participants, reducing bias in this study (Babbie, 2007).

The questionnaire was administered in English as this study targeted professionals. The authors appointed an agent to distribute the questionnaires in Tehran because the distance was a problem. There are acknowledged difficulties in administering a questionnaire in a jurisdiction outside of a researcher's location. The agent made a phone call to the identified audit firms with a brief overview of the research and asked them whether they are willing to participate. If audit firms showed their willingness to participate, the agent distributed the questionnaires among participants at their preferred time. However, if participants needed to have some time to respond to this query, the agent asked for an appropriate time to call them back. If participants were unwilling to participate the agent apologised them for the disturbance. The agent mailed the obtained responses to authors after the data collection.

\section{$\underline{\text { Sample }}$}

The working professionals of audit firms in Tehran are chosen as relevant participants for this study. The working accounting and audit professionals in Tehran are suitable participants because of their familiarity with audit processes and financial reporting in Iran. Following Best, Buckby, and Tan (2001), professionals are identified using Yellow Pages. The sample consists of 183 audit firms operating in Tehran. There was no coercion to participate in the study. The participants could answer as much or as little as they prefer. They showed their consent through submission of the questionnaire. This study obtains the responses of 40 participants, representing a response rate of $22 \%$, which is suitable to draw an acceptable statistical conclusion (Baruch \& Holtom, 2008).

\section{Reliability and Validity of the Questionnaire}

This study conducts a multivariate analysis of variance to determine the effects of participants' demographic characteristics on their perceptions regarding identified threats to auditor independence. Therefore, this study considers four different aspects of the participants' demographic information, as described in section I of the questionnaire. 
Qualification level of participants is grouped into the diploma, bachelor, master, and $\mathrm{PhD}$. They are coded from 1 to 4, respectively. Professional accounting qualification levels of participants are coded ' 0 ' (without any professional qualification) and ' 1 ' (with a professional qualification). The accounting experience level of participants are categorised between 1-3 years (coded as 1), 4-6 years (coded as 2), 7-9 years (coded as 3), and over ten years (coded as 4). Similarly, the occupational experience level of participants is categorised between 1-3 years (coded as 1), 4-6 years (coded as 2), 7-9 years (coded as 3), and over ten years (coded as 4).

Guttmann's lambda-2 is a better method than Cronbach's alpha to measure the reliability of a questionnaire (Osburn, 2000; Sijtsma, 2009). Thus, following previous research (López et al., 2013; Menold, Kaczmirek, Lenzner, \& Neusar, 2014; Tan, Hemmelgarn, Baumgardner, \& Tucker, 2017; Van der Ark, Van der Palm, \& Sijtsma, 2011), this study computes Guttmann's lambda-2 to determine the reliability of its questionnaire. Guttmann's lambda-2 is 0.60 , which is acceptable (Callender \& Osburn, 1979). Moreover, following Aghaei and Ranjbar (2016) and Sudalaimuthu and Jesintha (2011), this study uses a Kaiser-MeyerOlkin measure of sampling adequacy to assess the validity of its questionnaire. The test yields the value of 0.571 , which is above the acceptable value of 0.5 (Kaiser, 1974).

Because all samples are of equal size, the assumption of homogeneity of covariances across groups is not violated. This study, therefore, uses Wilks' lambda test (Leech, Barrett, \& Morgan, 2012). Moreover, it checks the bivariate scatterplots for multivariate normality (Korkmaz, Goksuluk, \& Zararsiz, 2014). This study considers the outcomes of the Levene's test for equality of variances to determine whether or not homogeneity of variances for different threats is violated (Gastwirth, Gel, \& Miao, 2009). Table 3 shows the outcomes of Levene's test.

Table 3. Levene's test for Equality of Variances for Threats to Auditor Independence in Iran

\begin{tabular}{|l|c|c|c|c|}
\hline Threats to Auditor Independence & F & df1 & df2 & Sig \\
\hline Perceptions regarding gifts and presents & 1.90 & 29 & 8 & 0.17 \\
\hline Perceptions regarding bribery & 3.75 & 29 & 8 & 0.03 \\
\hline Perceptions regarding long-term relationship & 0.88 & 29 & 8 & 0.63 \\
\hline $\begin{array}{l}\text { Perceptions regarding the prospects of } \\
\text { reappointment }\end{array}$ & 2.10 & 29 & 8 & 0.14 \\
\hline $\begin{array}{l}\text { Perceptions regarding non-existence of an audit } \\
\text { committee }\end{array}$ & 1.40 & 29 & 8 & 0.32 \\
\hline $\begin{array}{l}\text { Perceptions regarding auditors' lack of } \\
\text { competence }\end{array}$ & 2.05 & 29 & 8 & 0.15 \\
\hline
\end{tabular}

Perceptions regarding bribery is significant at $5 \%(p=0.03)$. Thus, the assumption of homogeneity of variances for bribery is violated (Ho, 2013). This study addresses this matter by transforming this variable to equalise the variances (Leech et al., 2012). It analyses the effects of participants' demographic characteristics on their perceptions regarding different threats. Table 4 presents the results 
Table 4. Wilks' lambda Test to Determine the Effects of Participants' Demographic Characteristics on their Perceptions Regarding Threats to Auditor Independence

\begin{tabular}{|l|c|c|c|c|}
\hline Variable & Value & $F$ & Sig & Partial Eta Squared \\
\hline Intercept & 0.00 & $135.18^{\mathrm{a}}$ & 0.00 & 1.00 \\
\hline EduQualification $^{\mathrm{b}}$ & 0.09 & 0.66 & 0.79 & 0.55 \\
\hline ProQualification $^{\mathrm{c}}$ & 0.58 & $0.37^{\mathrm{a}}$ & 0.86 & 0.42 \\
\hline AccExperience $^{\mathrm{d}}$ & 0.03 & 0.89 & 0.61 & 0.60 \\
\hline Occupation $^{\mathrm{e}}$ & 0.10 & $1.10^{\mathrm{a}}$ & 0.48 & 0.69 \\
\hline
\end{tabular}

a. Exact statistic, b. Educational qualification level of participants, c. Professional accounting qualification level of participants, d. Accounting experience level of participants, and e. Occupational experience level of participants.

Wilks' lambda test shows the results of the demographic variables and none is significant. Educational qualification level of participants obtains Wilks' $\Lambda=$ $0.09, p=0.79$, and multivariate $\eta^{2}=0.55$. Professional accounting qualification level of participants has Wilks' $\Lambda=0.58, p=0.86$, and multivariate $\eta^{2}=0.42$. Accounting experience level of participants obtains Wilks' $\Lambda=0.03, p=0.61$, and multivariate $\eta^{2}=0.60$. Lastly, occupational experience level of participants has Wilks' $\Lambda=0.10, p=0.48$, and multivariate $\eta^{2}=0.69$. This finding implies that participants' demographic characteristics do not affect their perceptions regarding threats to independence.

\section{Data Analysis}

First, this study assesses the quantitative results of the closed-ended questions in five forms of Likert scale measures. It compares the figures against each other to determine relative priorities for the Iranian regulator. Following Best et al. (2001), this study compares the mean differences between different threats to determine the participants' relative perceptions.

Second, this study uses open and axial coding to analyse the responses to the open-ended question. It conducts a detailed analysis of participants' responses to discover their views regarding their nominated threats. It categorises the nominated threats and assesses the relationships between different categories and their subcategories (Wicks, 2010). Moreover, it investigates the missing relationships by searching for potential relationships among different classes (Wicks, 2010). The open-ended question provides the most commonly cited threats by participants. This study uses NVivo to analyse the written responses (Dogui, Boiral, \& HerasSaizarbitoria, 2014; Dowling \& Leech, 2014). It identifies six primary themes (higher level coding) and ten categories (lower level coding).

This study analyses the collected data from financial media as follows. It compares triangulated thematic (financial corruption, financial scandal, audit failure, and accounting scandal) analysis of articles against the quantitative results in the first stage. It uses the following keywords to obtain the required information: "financial corruption, Iran"; "financial scandal, Iran"; "audit failure, Iran"; and "accounting scandal, Iran." The search terms are subjective in the sense that the evidence of accounting and reporting failures is necessary to observe the "worst case" scenario facing the Iranian financial and capital market. This study conducts 
a general search of Google and Persian news sites (such as Tabnak) to obtain the media articles. It selects reputable media sources with a given emphasis to British Broadcasting Corporation (BBC), Tribune Content Agency LLC, and Financial Times Limited. It disregards the articles that come from sources where reliability may be a concern.

\section{Results}

\section{Analysis of Participants' Responses to Likert Scale Questions}

Participants have various qualification levels. Twelve and a half percent have a high-school diploma, 37.5\% a bachelor's degree, 32.5\% a master's degree, and $17.5 \%$ have a doctoral degree. Seventy-two and a half percent do not have any professional accounting qualification. However, $5 \%, 7.5 \%$, and $15 \%$ of participants are a member of Iranian Accounting Association, Iranian Institute of Certified Accountants, and the Iranian Association of Certified Public Accountants, respectively. Two participants did not mention their accounting experience level. One is without any experience, $22.5 \%$ with 1 to 3 years of experience, $7.5 \%$ with 4 to 6 years, $35 \%$ with 7 to 9 years, and $27.5 \%$ with over ten years of experience. Twenty percent are accountants, $35 \%$ auditors, $5 \%$ consultants, and $40 \%$ are other professionals. Table 5 provides the participants' demographic information.

Table 5. Demographic Information of Participants of this Study

\begin{tabular}{|l|l|}
\hline Statements & Number of Participants \\
\hline Qualification level & \\
\hline High-school diploma & 5 \\
\hline Bachelor & 15 \\
\hline Master & 13 \\
\hline PhD & 7 \\
\hline Professional accounting qualification & \\
\hline No & 29 \\
\hline Iranian Accounting Association & 2 \\
\hline Iranian Association of Certified Public Accountants & 6 \\
\hline Iranian Institute of Certified Accountants & 3 \\
\hline Accounting experience & \\
\hline No & 1 \\
\hline $1-3$ years & 9 \\
\hline $4-6$ years & 3 \\
\hline $7-9$ years & 14 \\
\hline Over ten years & 11 \\
\hline Current occupation & \\
\hline Accountants & 8 \\
\hline Auditors & 14 \\
\hline Consultants & 2 \\
\hline Other professionals & 16 \\
\hline
\end{tabular}


Table 6 describes the participants' responses to Likert scale questions.

Table 6. Participants' Responses to Likert Scale Questions Regarding the Six Identified Threats to Auditor Independence in Iran

\begin{tabular}{|c|c|c|c|c|c|c|}
\hline & $\begin{array}{l}\text { Strongly } \\
\text { disagree }\end{array}$ & Disagree & $\begin{array}{c}\text { Neither agree } \\
\text { nor disagree }\end{array}$ & Agree & $\begin{array}{c}\text { Strongly } \\
\text { agree }\end{array}$ & Total \\
\hline Gifts and presents & $\begin{array}{c}9 \\
(22.5 \%)\end{array}$ & $\begin{array}{c}14 \\
(35 \%)\end{array}$ & $\begin{array}{c}3 \\
(7.5 \%)\end{array}$ & $\begin{array}{c}7 \\
(17.5 \%)\end{array}$ & $\begin{array}{c}7 \\
(17.5 \%)\end{array}$ & $\begin{array}{c}40 \\
(100 \%)\end{array}$ \\
\hline Bribery & $\begin{array}{c}1 \\
(2.5 \%)\end{array}$ & $\begin{array}{c}2 \\
(5 \%)\end{array}$ & $\begin{array}{c}2 \\
(5 \%)\end{array}$ & $\begin{array}{c}19 \\
(47.5 \%)\end{array}$ & $\begin{array}{c}16 \\
(40 \%)\end{array}$ & $\begin{array}{c}40 \\
(100 \%)\end{array}$ \\
\hline $\begin{array}{l}\text { Long-term } \\
\text { relationship }\end{array}$ & $\begin{array}{c}0 \\
(0 \%)\end{array}$ & $\begin{array}{c}8 \\
(20 \%) \\
\end{array}$ & $\begin{array}{c}9 \\
(22.5 \%) \\
\end{array}$ & $\begin{array}{c}19 \\
(47.5 \%) \\
\end{array}$ & $\begin{array}{c}4 \\
(10 \%)\end{array}$ & $\begin{array}{c}40 \\
(100 \%) \\
\end{array}$ \\
\hline $\begin{array}{l}\text { Prospects of } \\
\text { reappointment }\end{array}$ & $\begin{array}{c}2 \\
(5 \%)\end{array}$ & $\begin{array}{c}5 \\
(12.5 \%)\end{array}$ & $\begin{array}{c}7 \\
(17.5 \%)\end{array}$ & $\begin{array}{c}20 \\
(50 \%)\end{array}$ & $\begin{array}{c}6 \\
(15 \%)\end{array}$ & $\begin{array}{c}40 \\
(100 \%)\end{array}$ \\
\hline $\begin{array}{l}\text { Non-existence of } \\
\text { an audit committee }\end{array}$ & $\begin{array}{c}1 \\
(2.5 \%)\end{array}$ & $\begin{array}{c}3 \\
(7.5 \%)\end{array}$ & $\begin{array}{c}15 \\
(37.5 \%)\end{array}$ & $\begin{array}{c}18 \\
(45 \%)\end{array}$ & $\begin{array}{c}3 \\
(7.5 \%)\end{array}$ & $\begin{array}{c}40 \\
(100 \%)\end{array}$ \\
\hline $\begin{array}{l}\text { Auditors' lack of } \\
\text { competence }\end{array}$ & $\begin{array}{c}3 \\
(7.5 \%)\end{array}$ & $\begin{array}{c}11 \\
(27.5 \%)\end{array}$ & $\begin{array}{c}7 \\
(17.5 \%)\end{array}$ & $\begin{array}{c}12 \\
(30 \%)\end{array}$ & $\begin{array}{c}7 \\
(17.5 \%)\end{array}$ & $\begin{array}{c}40 \\
(100 \%)\end{array}$ \\
\hline
\end{tabular}

Following previous research (Bell, Causholli, \& Knechel, 2015; Best et al., 2001; Earley \& Kelly, 2004; Horvat \& Lipičnik, 2016), this study compares mean differences between different threats to determine the participants' perceptions about them. All threats, except gifts and presents, and auditors' lack of competence, are statistically significant at $1 \%$. Bribery obtains the highest mean (4.18), followed by prospects of reappointment (3.58). Long-term relationship and nonexistence of an audit committee have an identical mean of 3.48 , followed by auditors' lack of competence at 3.23. Gifts and presents obtain the lowest mean (2.73). Therefore, participants consider bribery as the strongest threat to auditor independence in Iran. The prospects of reappointment are the second most important threat. Long-term relationship and non-existence of an audit committee are equally the next important threats. The consideration of a long-term relationship between auditors and their clients and non-existence of an audit committee as threats to auditor independence is consistent with prior international studies as it was discussed in the literature review section. Gifts and presents, and auditors' lack of competence are not statistically significant threats to independence. Table 7 shows the participants' perceptions of different threats.

Table 7. T-test of Participants' Perceptions Regarding the Identified Threats to Auditor Independence in Iran

\begin{tabular}{|c|c|c|c|c|c|c|}
\hline Threats to Auditor Independence & $\mathrm{N}$ & Mean & $\mathrm{SD}$ & Mean Difference & $\mathrm{t}$ & $p$-value \\
\hline Gifts and presents & 40 & 2.73 & 1.45 & -0.27 & -1.20 & 0.238 \\
\hline Bribery & 40 & 4.18 & 0.93 & 1.18 & 7.99 & 0.000 \\
\hline Long-term relationship & 40 & 3.48 & 0.93 & 0.48 & 3.22 & 0.003 \\
\hline Prospects of reappointment & 40 & 3.58 & 1.06 & 0.58 & 3.43 & 0.001 \\
\hline Non-existence of an audit committee & 40 & 3.48 & 0.85 & 0.48 & 3.55 & 0.001 \\
\hline Auditors' lack of competence & 40 & 3.23 & 1.25 & 0.23 & 1.14 & 0.262 \\
\hline
\end{tabular}

$\mathrm{N}=$ Number of observations 
Bribery

Transparency International's "Corruption Perceptions Index" scores Iran at $27 / 100$. The scores range from 0 to 100 , where 100 is "very clean". Transparency International ranks Iran at the $136^{\text {th }}$ place out of 175 nations (Transparency International, 2014). Iran has suffered from many reported scandals involving fraud. For instance, the Iranian banking system experienced embezzlement of 2.6 billion USD in 2011, which is the biggest embezzlement case in its history (Shushter, 2011). High frequency and profile corruptions have attracted regulatory emphases from the Iranian Supreme Leader and other regulators. For example, the Iranian Supreme Leader, on various occasions, has instructed the heads of government, judiciary system, and parliament to combat financial corruption (BBC, 2008). This background as to fraud, bribery, and corruption in Iran justifies the participants' consideration of bribery as the strongest threat to auditor independence.

\section{Gifts and Presents}

As mentioned before, participants disregard gifts and presents as posing significant threats to auditor independence in Iran. An Iranian employee may bring some cakes to share with his colleagues, without aiming to get something in return (Kwintessential Ltd, 2014). Iranians offer money or gold coins on religious holidays and give gifts on various celebratory occasions such as weddings, successful business deals, or graduations (Iran Visitor, 2015). A host may offer his guest anything that looks attractive in his house as a gift (Betteridge, 1985). The participants' ignorance of gifts as independence threats may show the influence of the Iranian culture on their perceptions. It may show the effect of cultural differences between Iran and countries that do not traditionally perceive gifts in a similar way to Iranians within the audit profession.

\section{Auditors' Lack of Competence}

Prior Iranian research considers auditor's incompetency an independence threat (Mansouri et al., 2009; Salehi \& Husini, 2011). However, this study dismisses prior studies' finding. Similar to gifts and presents, a lack of competence is not a significant threat to auditor independence in Iran. This finding aligns with the provision of IAO's 2014 framework where auditor incompetence is not on the list of threats to independence. However, IFAC requires auditors to be competent to perform their tasks. They should have adequate knowledge and experience of audit assignments that they undertake and a good knowledge and understanding of their clients' business and industry (IFAC, 2014b).

\section{Analysis of Participants' Responses to the Open-ended Question}

Twenty-nine participants respond to the final question in the questionnaire by nominating other threats to auditor independence than those mentioned in the 
questionnaire. Six professionals choose multiple threats. This study obtains 37 instances of new information, suggesting some new threats to independence. Table 8 shows the participants' responses to the open-ended question.

Table 8. Participants' Responses to the Open-Ended Question of this Study

\begin{tabular}{|c|c|}
\hline $\begin{array}{l}\text { Participant } \\
\text { No }\end{array}$ & Quote \\
\hline 1 & Economic instability is a threat. \\
\hline 2 & In my opinion, weak economy of Iran is a threat. \\
\hline 3 & Management fraud \\
\hline 4 & The small income of auditors and excessive bureaucracy \\
\hline 5 & Bureaucracy and non-auditing services \\
\hline 6 & $\begin{array}{l}\text { Not-audit-related-services may be indicators of a threat to auditor } \\
\text { independence. }\end{array}$ \\
\hline 7 & $\begin{array}{c}\text { In my opinion auditors' consulting services are signs of a threat to } \\
\text { auditor independence in Iran. }\end{array}$ \\
\hline 8 & Auditors' competition and their advisory services \\
\hline 9 & The high auditor's fee and small size of audit firms \\
\hline 10 & $\begin{array}{l}\text { The pressure from management is a threat to auditor independence } \\
\text { in Iran. }\end{array}$ \\
\hline 11 & Auditors' advisory and consulting services \\
\hline 12 & $\begin{array}{c}\text { The auditors' low income may be an indicator of threat to auditor } \\
\text { independence in my opinion. }\end{array}$ \\
\hline 13 & The management's wrongdoing \\
\hline 14 & $\begin{array}{c}\text { Providing management advisory services by auditors may be a } \\
\text { threat to auditor independence. }\end{array}$ \\
\hline 15 & I think competition among the auditors is another indicator. \\
\hline 16 & Poor infrastructure of the Iranian audit firms \\
\hline 17 & Significant amount of fees \\
\hline 18 & The auditors' low salary is another factor. \\
\hline 19 & $\begin{array}{l}\text { The small size of the Iranian audit firms is another indicator of } \\
\text { threat to auditor independence. }\end{array}$ \\
\hline 20 & $\begin{array}{l}\text { The high amount of auditor's unemployment can be another threat } \\
\text { to auditor independence in Iran in my opinion. }\end{array}$ \\
\hline 21 & Providing consulting and advisory services to managers \\
\hline 22 & The high unemployment rate of auditors \\
\hline 23 & Pressure from management \\
\hline 24 & $\begin{array}{l}\text { If the auditors sincerely report, they may lose their job. This fear is } \\
\text { a threat to their independence. }\end{array}$ \\
\hline 25 & $\begin{array}{l}\text { The fact that auditors have to do lots of work and their salary is not } \\
\text { enough, encouraging them for wrongdoing. }\end{array}$ \\
\hline 26 & $\begin{array}{l}\text { In my opinion, high competition between the audit firms and } \\
\text { providing consulting services to management are indicators of a } \\
\text { threat to auditor independence in Iran. }\end{array}$ \\
\hline 27 & $\begin{array}{l}\text { In my view, the dependency of audit firms to their major clients can } \\
\text { be a danger for their objectivity in Iran. }\end{array}$ \\
\hline 28 & Bad financial condition of auditors \\
\hline 29 & $\begin{array}{l}\text { When the audit firms provide other services to their clients except } \\
\text { for their routine services }\end{array}$ \\
\hline
\end{tabular}


Table 9 describes the identified themes and categories based on participants' responses to the open-ended question.

Table 9. Identified Themes and Categories Based on Participants' Responses to the Open-ended Question

\begin{tabular}{|c|c|c|c|}
\hline Themes & Categories & Definition & Instances \\
\hline $\begin{array}{l}\text { Competition } \\
\text { among audit } \\
\text { firms }\end{array}$ & $\begin{array}{l}\text { Competition among } \\
\text { audit firms }\end{array}$ & $\begin{array}{l}\text { High competition level } \\
\text { among Iranian audit firms }\end{array}$ & 3 \\
\hline High audit fees & High audit fees & $\begin{array}{l}\text { Clients' provision of high } \\
\text { audit fees to auditors }\end{array}$ & 3 \\
\hline \multirow{2}{*}{$\begin{array}{l}\text { Iran's economic } \\
\text { condition }\end{array}$} & $\begin{array}{l}\text { High unemployment } \\
\text { rate of auditors }\end{array}$ & $\begin{array}{c}\text { Large number of } \\
\text { unemployed accountants in } \\
\text { Iran } \\
\end{array}$ & 2 \\
\hline & $\begin{array}{l}\text { Low income of } \\
\text { auditors, weak } \\
\text { economy of Iran }\end{array}$ & $\begin{array}{l}\text { Small revenue of Iranian } \\
\text { accountants, existing poor } \\
\text { economic condition in Iran }\end{array}$ & 7 \\
\hline \multirow{2}{*}{$\begin{array}{l}\text { Management's } \\
\text { wrongdoings }\end{array}$} & Management fraud & $\begin{array}{c}\text { Fraudulent activities } \\
\text { perpetrated by management }\end{array}$ & 3 \\
\hline & Management pressure & $\begin{array}{c}\text { Pressure from management } \\
\text { to guide auditors towards a } \\
\text { particular direction }\end{array}$ & 3 \\
\hline \multirow{2}{*}{$\begin{array}{l}\text { Non-audit } \\
\text { services }\end{array}$} & $\begin{array}{l}\text { Management advisory } \\
\text { services }\end{array}$ & $\begin{array}{l}\text { Auditors' provision of } \\
\text { consulting services for their } \\
\text { clients' management }\end{array}$ & 5 \\
\hline & Consultancy services & $\begin{array}{l}\text { Auditors' provision of } \\
\text { different types of advisory } \\
\text { services for their client firms }\end{array}$ & 6 \\
\hline \multirow{2}{*}{$\begin{array}{l}\text { Poor } \\
\text { infrastructure of } \\
\text { audit firms }\end{array}$} & Bureaucracy & $\begin{array}{c}\text { Complicated system of } \\
\text { Iranian audit firms }\end{array}$ & 2 \\
\hline & $\begin{array}{l}\text { Small size of audit } \\
\text { firms }\end{array}$ & $\begin{array}{c}\text { Small size of Iranian audit } \\
\text { firms }\end{array}$ & 3 \\
\hline
\end{tabular}

An evaluation of this component of the questionnaire shows that eleven participants nominate non-audit services, nine Iran's economic condition, six management's wrongdoings, five poor infrastructure of audit firms, three competition between audit firms, and three consider high audit fees as threats to auditor independence in Iran. The largest number of responses consider non-audit services and Iran's economic condition as 'other' threats. This consideration of non-audit services as a threat is consistent with prior international academic literature (Campa \& Donnelly, 2016; Causholli, Chambers, \& Payne, 2014, 2015; Quick \& Warming-Rasmussen, 2015). 


\section{$\underline{\text { Non-audit Services }}$}

A provision of non-audit services may result in self-interest, self-review, and advocacy threats (IFAC, 2014b). Prior international studies document that nonaudit services may impair auditor independence (Ashbaugh, LaFond, \& Mayhew, 2003; Francis \& Ke, 2006; Kinney, Palmrose, \& Scholz, 2004; Rankin, 2004). Non-audit services increase auditors' financial dependency on their auditees, reducing their desire to disagree with their clients' requirements (DeFond et al., 2002). They discourage audit firms from issuing a qualified audit opinion (Hay, Knechel, \& Li, 2006b). For example, auditors may issue a clean audit report for financial statements of a company which do not comply with auditing standards (Kinney et al., 2004). Moreover, the consultancy nature of non-audit services brings bias to auditors' judgement (SEC, 2000).

\section{$\underline{\text { Iran's Economic Condition }}$}

Participants nominate Iran's economic condition as another threat to auditor independence. For example, a participant mentions that:

"The high amount of auditor's unemployment can be another threat to auditor independence in Iran in my opinion."

Another respondent mentions that:

"The auditors' low income may be an indicator of threat to auditor independence in my opinion."

Iran is one of the youngest countries in the world. Thirty-five percent of Iranians are aged between 15 and 29. Moreover, Iran has a rapid population growth, wherein the size of the Iranian labour force grew by $2 \%$ every year during the 2014-2018 period (The Economist Intelligence Unit N.A., 2014). Iran's rapid population growth highlights its need for better employment. However, its unemployment rate is the $16^{\text {th }}$ highest in the world, and the country faces an unemployment rate of over $12 \%$. This rate is higher for women and university graduates. University graduates struggle to find a job. Many educated Iranians work in fields that are unrelated to their specialisation. They may even need to have two or more jobs to survive (Bozorgmehr, 2012). According to the Iranian Deputy Labour Minister, Abu-Hassan Firouz-Abadi, around 200,000 Iranians were receiving unemployment benefits in 2014. Abu-Hassan Firouz-Abadi considers high unemployment rate a major challenge for the Iranian government (Anonymous, 2014a). Similarly, the head of Iran's Workers House warns regarding potential workers' crisis (Bozorgmehr, 2012).

International sanctions have decreased economic growth rate of Iran, increasing its unemployment rate. Unemployment remains a major concern for young Iranians, while their country is under sanction (The Economist Intelligence Unit N.A., 2014). According to a former representative of the International Labour Organisation, wrong economic policies have increased unemployment rate in Iran. 
The former Iranian president, Mahmoud Ahmadinejat, has focused on offering loans to jobseekers rather than funding infrastructure projects. A reduction in energy subsidies for households and industry has damaged the Iranian economy (Bozorgmehr, 2012). The ease of international sanctions as a result of Iran's agreement with world powers over its nuclear programme along with a policy of reduction of energy subsidies of the new president, Hassan Rouhani, has reduced inflation rate in the country. The new government is scaling back the cash subsidies that were handed out by the former government, leading to a reduction of the inflation rate from $45 \%$ to $15 \%$ in 2014 (Anonymous, 2014b). The harsh economic condition may encourage auditors to give in to their clients' desire to maintain their income. This leniency can become greater for dependence on higher fees because auditors are more likely to impair their independence to retain their valuable clients (Lim \& Tan, 2010).

\section{Media Articles and Findings}

This study analyses 49 media articles of different sources for the period 1994 - 2014. It limits its analysis to 2014 as IAO issued the auditor independence framework in 2014. The articles are analysed in chronological order, wherein " 1 " is assigned to the most recent article and " 49 " to the oldest article. This study categorises the articles based on their contents into two broad categories of regulatory and economic perspectives. Regulatory perspectives encompass Iran's aspiration to join the international community, and economic perspectives capture articles that refer to economic losses of wrongdoings. Majority of sources have economic perspectives. An evaluation of keywords and publication sources shows that various media sources (such as BBC) frequently discuss financial corruption in the Iranian economy. Moreover, they often criticise IAO. Table 10 describes the entire sample of examined media articles.

Table 10. Description of the Examined Media Articles Including their Titles, Publication Dates, and Keywords and Sources Used to Obtain Them

\begin{tabular}{|c|c|c|c|c|}
\hline $\begin{array}{c}\text { Article- } \\
\text { No }\end{array}$ & Keyword & Title & Source & Date \\
\hline \multicolumn{5}{|c|}{ Panel A Regulatory Perspectives } \\
\hline 1 & $\begin{array}{c}\text { Financial } \\
\text { corruption, } \\
\text { Iran }\end{array}$ & $\begin{array}{c}\text { Rouhani confronts } \\
\text { Iran's hardliners on } \\
\text { corruption }\end{array}$ & $\begin{array}{c}\text { The Financial } \\
\text { Times Limited }\end{array}$ & $8 / 12 / 2014$ \\
\hline 7 & Fraud, Iran & $\begin{array}{c}\text { The Iranian } \\
\text { government's plan to } \\
\text { prevent occurrence of } \\
\text { fraud in future }\end{array}$ & Tabnak & $1 / 05 / 2014$ \\
\hline 8 & $\begin{array}{c}\text { Financial } \\
\text { corruption, } \\
\text { Iran }\end{array}$ & $\begin{array}{c}\text { Iran president orders } \\
\text { fight against financial } \\
\text { corruption }\end{array}$ & BBC & $2 / 02 / 2014$ \\
\hline 9 & $\begin{array}{c}\text { Financial } \\
\text { corruption, } \\
\text { Iran }\end{array}$ & $\begin{array}{c}\text { BBC Monitoring quotes } \\
\text { from Iranian press 01 } \\
\text { Feb 2014 }\end{array}$ & BBC & $1 / 02 / 2014$ \\
\hline
\end{tabular}




\begin{tabular}{|c|c|c|c|c|}
\hline 10 & $\begin{array}{l}\text { Financial } \\
\text { corruption, } \\
\text { Iran }\end{array}$ & $\begin{array}{c}\text { Iran intelligence } \\
\text { minister opposes } \\
\text { publicising financial } \\
\text { corruption }\end{array}$ & $\mathrm{BBC}$ & $14 / 01 / 2014$ \\
\hline 11 & $\begin{array}{l}\text { Financial } \\
\text { corruption, } \\
\text { Iran }\end{array}$ & $\begin{array}{c}\text { Iran arrests business } \\
\text { tycoon over corruption } \\
\text { scandal }\end{array}$ & $\begin{array}{c}\text { Indo Asian News } \\
\text { Service }\end{array}$ & $5 / 01 / 2014$ \\
\hline 14 & $\begin{array}{c}\text { Audit } \\
\text { failure, Iran }\end{array}$ & $\begin{array}{c}\text { Iran MP urges } \\
\text { government to pay } \\
\text { attention to tax revenues }\end{array}$ & $\mathrm{BBC}$ & $31 / 12 / 2013$ \\
\hline 16 & Fraud, Iran & $\begin{array}{l}\text { Keeping our eyes on } \\
\text { Iran }\end{array}$ & $\begin{array}{l}\text { The Jerusalem } \\
\text { Post Ltd }\end{array}$ & $25 / 06 / 2013$ \\
\hline 17 & Fraud, Iran & $\begin{array}{l}\text { Iran Islamic Republic } \\
\text { of, United States: } \\
\text { Treasury targets } \\
\text { network attempting to } \\
\text { evade Iran sanctions }\end{array}$ & $\begin{array}{l}\text { Albawaba } \\
\text { (London) Ltd }\end{array}$ & $12 / 04 / 2013$ \\
\hline 19 & $\begin{array}{l}\text { Financial } \\
\text { corruption, } \\
\text { Iran }\end{array}$ & $\begin{array}{c}\text { Iran Speaker says } \\
\text { "intelligence chiefs" } \\
\text { involved in financial } \\
\text { corruption }\end{array}$ & $\mathrm{BBC}$ & $7 / 01 / 2013$ \\
\hline 24 & $\begin{array}{l}\text { Financial } \\
\text { corruption, } \\
\text { Iran }\end{array}$ & $\begin{array}{c}\text { Commentary terms } \\
\text { embezzlement in Iran } \\
\text { unforgivable act }\end{array}$ & $\mathrm{BBC}$ & $3 / 07 / 2012$ \\
\hline 25 & $\begin{array}{l}\text { Financial } \\
\text { corruption, } \\
\text { Iran }\end{array}$ & $\begin{array}{l}\text { 'State' bodies stymie } \\
\text { Iran privatisations }\end{array}$ & $\begin{array}{l}\text { The Financial } \\
\text { Times Limited }\end{array}$ & $30 / 05 / 2012$ \\
\hline 33 & $\begin{array}{l}\text { Financial } \\
\text { corruption, } \\
\text { Iran }\end{array}$ & $\begin{array}{l}\text { Iran MPs urge Judiciary } \\
\text { to follow up financial } \\
\text { corruption network's } \\
\text { case }\end{array}$ & $\mathrm{BBC}$ & $10 / 03 / 2010$ \\
\hline 35 & $\begin{array}{l}\text { Financial } \\
\text { corruption, } \\
\text { Iran }\end{array}$ & $\begin{array}{l}\text { Iran's creeping } \\
\text { corruption }\end{array}$ & $\begin{array}{c}\text { IBT Media, Inc., } \\
\text { The } \\
\text { Newsweek/Daily } \\
\text { Beast Company } \\
\text { LLC } \\
\end{array}$ & $30 / 11 / 2009$ \\
\hline 40 & $\begin{array}{l}\text { Financial } \\
\text { corruption, } \\
\text { Iran }\end{array}$ & $\begin{array}{l}\text { Iran leader calls for } \\
\text { continuation of } \\
\text { campaign against } \\
\text { financial corruption }\end{array}$ & $\mathrm{BBC}$ & $25 / 06 / 2008$ \\
\hline 42 & $\begin{array}{l}\text { Financial } \\
\text { corruption, } \\
\text { Iran }\end{array}$ & $\begin{array}{l}\text { Iran's new attempt to } \\
\text { privatise state-owned } \\
\text { enterprises }\end{array}$ & $\mathrm{BBC}$ & $31 / 07 / 2006$ \\
\hline 43 & $\begin{array}{l}\text { Financial } \\
\text { corruption, } \\
\text { Iran }\end{array}$ & $\begin{array}{c}\text { Iran's presence at World } \\
\text { Trade Organisation } \\
\text { inevitable - former } \\
\text { president }\end{array}$ & $\mathrm{BBC}$ & $25 / 01 / 2006$ \\
\hline
\end{tabular}




\begin{tabular}{|c|c|c|c|c|}
\hline 46 & $\begin{array}{l}\text { Financial } \\
\text { corruption, } \\
\text { Iran }\end{array}$ & $\begin{array}{l}\text { Single forex rate to curb } \\
\text { financial corruption in } \\
\text { Iran: Official }\end{array}$ & $\begin{array}{c}\text { Middle East News } \\
\text { Online }\end{array}$ & $4 / 03 / 2002$ \\
\hline \multicolumn{5}{|c|}{ Panel B Economic Perspectives } \\
\hline 2 & $\begin{array}{c}\text { Audit } \\
\text { failure, Iran }\end{array}$ & $\begin{array}{l}\text { US watchdog fines } \\
\text { Standard Chartered for } \\
\text { second time: Money- } \\
\text { laundering failure costs } \\
\text { bank further } \$ 300 \mathrm{~m} \text { : } \\
\text { High-risk dealings went } \\
\text { undetected, says } \\
\text { regulator }\end{array}$ & $\begin{array}{c}\text { Guardian News \& } \\
\text { Media Limited }\end{array}$ & $20 / 08 / 2014$ \\
\hline 3 & $\begin{array}{c}\text { Audit } \\
\text { failure, Iran }\end{array}$ & $\begin{array}{l}\text { Iran official dismisses } \\
\text { Audit Court report on } \\
\text { oil sale to UAE }\end{array}$ & $\mathrm{BBC}$ & $23 / 07 / 2014$ \\
\hline 4 & Fraud, Iran & $\begin{array}{l}\text { Supreme Audit Court of } \\
\text { Iran confirms } \\
\text { government's taking } \\
\$ 4.1 \text { billion out of NDF }\end{array}$ & $\begin{array}{c}\text { Tribune Content } \\
\text { Agency LLC }\end{array}$ & $28 / 05 / 2014$ \\
\hline 5 & $\begin{array}{l}\text { Accounting } \\
\text { scandal, Iran }\end{array}$ & $\begin{array}{l}\text { Brief: Iran dismisses } \\
\text { scandal of selling } \\
\text { recorded phone talks }\end{array}$ & $\begin{array}{c}\text { Tribune Content } \\
\text { Agency LLC }\end{array}$ & $20 / 05 / 2014$ \\
\hline 6 & $\begin{array}{l}\text { Financial } \\
\text { corruption, } \\
\text { Iran } \\
\end{array}$ & $\begin{array}{l}\text { Fugitive accused of } \\
\text { financial corruption } \\
\text { handed over to Iran }\end{array}$ & $\begin{array}{c}\text { Tribune Content } \\
\text { Agency LLC }\end{array}$ & $7 / 05 / 2014$ \\
\hline 12 & $\begin{array}{l}\text { Financial } \\
\text { corruption, } \\
\text { Iran }\end{array}$ & $\begin{array}{c}\text { Iran daily discusses } \\
\text { financial corruption in } \\
\text { Turkey }\end{array}$ & $\mathrm{BBC}$ & $3 / 01 / 2014$ \\
\hline 13 & $\begin{array}{c}\text { Audit } \\
\text { failure, Iran }\end{array}$ & $\begin{array}{l}\text { Iran government } \\
\text { neglects tax revenue due } \\
\text { to high oil income }\end{array}$ & $\mathrm{BBC}$ & $1 / 01 / 2014$ \\
\hline 15 & $\begin{array}{c}\text { Audit } \\
\text { failure, Iran }\end{array}$ & $\begin{array}{c}\text { Iran Audit Court accuses } \\
\text { president of } \\
\text { misspending surplus } \\
\text { revenues }\end{array}$ & $\mathrm{BBC}$ & $25 / 06 / 2013$ \\
\hline 18 & $\begin{array}{l}\text { Financial } \\
\text { corruption, } \\
\text { Iran }\end{array}$ & $\begin{array}{l}\text { Iran: Corruption case } \\
\text { raises Iran domestic } \\
\text { tensions }\end{array}$ & Al Jazeera & $4 / 02 / 2013$ \\
\hline 20 & $\begin{array}{l}\text { Accounting } \\
\text { scandal, Iran }\end{array}$ & $\begin{array}{l}\text { Standard Chartered bank } \\
\text { accused of scheming } \\
\text { with Iran to hide } \\
\text { transactions }\end{array}$ & $\begin{array}{c}\text { Guardian News \& } \\
\text { Media Limited }\end{array}$ & $7 / 08 / 2012$ \\
\hline
\end{tabular}




\begin{tabular}{|c|c|c|c|c|}
\hline 21 & $\begin{array}{l}\text { Accounting } \\
\text { scandal, Iran }\end{array}$ & $\begin{array}{l}\text { Standard Chartered } \\
\text { diving despite Iran } \\
\text { scandal denial }\end{array}$ & $\begin{array}{l}\text { Evening Standard } \\
\text { Limited, Solo } \\
\text { Syndication, a } \\
\text { division of } \\
\text { Associated } \\
\text { Newspapers Ltd } \\
\end{array}$ & $7 / 08 / 2012$ \\
\hline 22 & $\begin{array}{l}\text { Accounting } \\
\text { scandal, Iran }\end{array}$ & $\begin{array}{c}\text { Death terms in Iran bank } \\
\text { scandal }\end{array}$ & Al Jazeera & $30 / 07 / 2012$ \\
\hline 23 & $\begin{array}{c}\text { Accounting } \\
\text { scandal, Iran }\end{array}$ & $\begin{array}{l}\text { Iran bank fraud scandal: } \\
4 \text { sentenced to death }\end{array}$ & Yeganeh & $30 / 07 / 2012$ \\
\hline 26 & $\begin{array}{l}\text { Financial } \\
\text { corruption, } \\
\text { Iran }\end{array}$ & $\begin{array}{c}\text { Brief: MP: Corruption } \\
\text { costs Iran } \$ 34 \text { billion a } \\
\text { year }\end{array}$ & $\begin{array}{l}\text { Tribune Content } \\
\text { Agency LLC }\end{array}$ & $18 / 12 / 2011$ \\
\hline 27 & $\begin{array}{l}\text { Audit } \\
\text { failure, Iran }\end{array}$ & $\begin{array}{l}\text { Iran Audit Court sends } \\
\text { report on government } \\
\text { "violations" to judiciary }\end{array}$ & $\mathrm{BBC}$ & $17 / 12 / 2011$ \\
\hline 28 & $\begin{array}{l}\text { Accounting } \\
\text { scandal, Iran }\end{array}$ & $\begin{array}{l}\text { Iran arrests relative of } \\
\text { president's aid over } \\
\text { embezzlement scandal }\end{array}$ & $\begin{array}{l}\text { Xinhua News } \\
\text { Agency }\end{array}$ & $8 / 11 / 2011$ \\
\hline 29 & Fraud, Iran & $\begin{array}{l}\text { Two other suspects } \\
\text { arrested over Iran's } \\
\text { embezzlement case }\end{array}$ & $\begin{array}{l}\text { Tribune Content } \\
\text { Agency LLC }\end{array}$ & $28 / 10 / 2011$ \\
\hline 30 & $\begin{array}{l}\text { Accounting } \\
\text { scandal, Iran }\end{array}$ & $\begin{array}{l}\text { Iran's largest banks } \\
\text { swindled out of } \$ 2.6 \\
\text { Billion }\end{array}$ & NPR & $27 / 10 / 2011$ \\
\hline 31 & $\begin{array}{l}\text { Accounting } \\
\text { scandal, Iran }\end{array}$ & $\begin{array}{l}\text { Quds Force linked to } \\
\text { bank in Iran scandal }\end{array}$ & $\begin{array}{l}\text { The Globe \& Mail } \\
\text { division of Bell } \\
\text { Globe media } \\
\text { Publishing Inc. }\end{array}$ & $12 / 10 / 2011$ \\
\hline 32 & $\begin{array}{l}\text { Accounting } \\
\text { scandal, Iran }\end{array}$ & $\begin{array}{l}\text { Israeli billionaire at } \\
\text { heart of Iran trade } \\
\text { scandal dies }\end{array}$ & $\begin{array}{l}\text { The Financial } \\
\text { Times Limited }\end{array}$ & $3 / 06 / 2011$ \\
\hline 34 & $\begin{array}{l}\text { Financial } \\
\text { corruption, } \\
\text { Iran } \\
\end{array}$ & $\begin{array}{l}\text { Iran arrests } 15 \text { members } \\
\text { of "financial corruption } \\
\text { network" }\end{array}$ & $\mathrm{BBC}$ & $30 / 01 / 2010$ \\
\hline 36 & Fraud, Iran & $\begin{array}{c}\text { Iran: "Iran's missing oil } \\
\text { money" }\end{array}$ & $\begin{array}{l}\text { Thai News } \\
\text { Service Group }\end{array}$ & $8 / 05 / 2009$ \\
\hline 37 & Fraud, Iran & $\begin{array}{l}\text { Iran: In search of } \$ 1 b \\
\text { missing oil money in } \\
\text { Iran }\end{array}$ & $\begin{array}{l}\text { Thai News } \\
\text { Service Group }\end{array}$ & $16 / 02 / 2009$ \\
\hline 38 & Fraud, Iran & $\begin{array}{c}\text { Iran minister sacked } \\
\text { over forgery }\end{array}$ & $\mathrm{BBC}$ & $4 / 11 / 2008$ \\
\hline 39 & $\begin{array}{l}\text { Financial } \\
\text { corruption, } \\
\text { Iran }\end{array}$ & $\begin{array}{l}\text { Iran charges seven with } \\
\text { financial corruption }\end{array}$ & $\mathrm{BBC}$ & $14 / 07 / 2008$ \\
\hline
\end{tabular}




\begin{tabular}{|c|c|c|c|c|}
\hline 41 & $\begin{array}{c}\text { Audit } \\
\text { failure, Iran }\end{array}$ & $\begin{array}{c}\text { President orders } \\
\text { dismissal of Iran } \\
\text { Insurance's board of } \\
\text { directors }\end{array}$ & BBC & $9 / 05 / 2007$ \\
\hline 44 & $\begin{array}{c}\text { Financial } \\
\text { corruption, } \\
\text { Iran }\end{array}$ & $\begin{array}{c}\text { Halliburton's activities } \\
\text { suspended in Iran }\end{array}$ & BBC & $22 / 08 / 2005$ \\
\hline 45 & $\begin{array}{c}\text { Accounting } \\
\text { scandal, Iran }\end{array}$ & $\begin{array}{c}\text { Iran: Oil Ministry to } \\
\text { complain against } \\
\text { Norway over Statoil } \\
\text { scandal }\end{array}$ & BBC & $9 / 11 / 2003$ \\
\hline 47 & $\begin{array}{c}\text { Financial } \\
\text { corruption, } \\
\text { Iran }\end{array}$ & $\begin{array}{c}\text { World: Middle East } \\
\text { Tehran mayor sentence } \\
\text { reduced }\end{array}$ & BBC & $24 / 12 / 1998$ \\
\hline 48 & $\begin{array}{c}\text { Accounting } \\
\text { scandal, Iran }\end{array}$ & $\begin{array}{c}\text { Tehran mayor is } \\
\text { arrested, accused of } \\
\text { embezzlement }\end{array}$ & Deseret News & $5 / 04 / 1998$ \\
\hline 49 & $\begin{array}{c}\text { Financial } \\
\text { corruption, } \\
\text { Iran }\end{array}$ & $\begin{array}{c}\text { Iran needs foreign } \\
\text { investment }\end{array}$ & Chemical Week & $20 / 07 / 1994$ \\
\hline
\end{tabular}

Triangulation of financial media analysis against the questionnaire results suggests that bribery frequently occurs in Iran. Thirteen of 49 articles (26.5\%) show that bribery exists in the country, justifying its consideration as the most serious independence threat by participants. For example, article 41 with the title of "president orders dismissal of Iran Insurance's board of directors" shows that the president orders this dismissal because of a State Audit Office's report regarding extensive scandal cases in the insurance company.

An analysis of the economic impacts of wrongdoings shows that they severely damage the country, causing Iran to lose billions of dollars. For example, article 4 with the title of "Supreme Audit Court of Iran confirms government's taking \$4.1 billion out of NDF" describes how the government illegally took large money out of the National Development Fund. The analysis supports participants' nomination of Iran's economic condition as a threat to auditor independence. An examination of gifts shows that they are not discussed in media articles, supporting participants' view to disregard them as threats.

\section{Robustness Checks}

This study performs two robustness checks to verify its findings.

\section{Friedman Test}

This study conducts a Friedman test to prioritise different threats to auditor independence, following (Salehi, 2011). The test shows a statistically significant difference in perceptions regarding different threats to auditor independence, $X^{2}(2)$ $=31.883, p=0.000$. Table 11 presents the results. 
Table 11. Friedman test to Prioritise Different Threats to Auditor Independence in Iran

\begin{tabular}{|l|c|c|c|c|c|}
\hline & $\mathrm{N}$ & $25^{\text {th }}$ & Median & $75^{\text {th }}$ & Mean \\
\hline The Perceptions regarding gifts & 40 & 2.000 & 2.000 & 4.000 & 2.610 \\
\hline The Perceptions regarding bribery & 40 & 4.000 & 4.000 & 5.000 & 4.700 \\
\hline $\begin{array}{l}\text { The Perceptions regarding long-term } \\
\text { relationship }\end{array}$ & 40 & 3.000 & 4.000 & 4.000 & 3.460 \\
\hline $\begin{array}{l}\text { The Perceptions regarding the prospects of } \\
\text { reappointment }\end{array}$ & 40 & 3.000 & 4.000 & 4.000 & 3.700 \\
\hline $\begin{array}{l}\text { The Perceptions regarding non-existence of } \\
\text { audit committee }\end{array}$ & 40 & 3.000 & 4.000 & 4.000 & 3.380 \\
\hline $\begin{array}{l}\text { The Perceptions regarding auditors' lack of } \\
\text { competence }\end{array}$ & 40 & 2.000 & 3.000 & 4.000 & 3.150 \\
\hline
\end{tabular}

$\mathrm{N}=$ Number of observations.

The perceptions regarding bribery obtain the highest mean (4.700), suggesting that participants consider bribery as the most severe threat.

\section{$\underline{\text { Exclusion of Gifts and Presents and Auditors' Lack of Competence }}$}

This study does not find 'gifts and presents' and auditors' lack of competence as significant threats to auditor independence in Iran. Hence, it excludes them to re-estimate the findings regarding different threats. Table 12 shows the outcomes.

Table 12. T-test of Participants' Perceptions Regarding Identified Threats to Auditor Independence without Gifts and Auditors' Lack of Competence

\begin{tabular}{|l|c|c|c|c|c|c|}
\hline $\begin{array}{l}\text { Threats to Auditor } \\
\text { Independence }\end{array}$ & $\mathrm{N}$ & Mean & $\mathrm{SD}$ & Mean Difference & $\mathrm{t}$ & $p$-value \\
\hline Bribery & 40 & 4.18 & 0.93 & 1.18 & 28.37 & 0.000 \\
\hline Long-term relationship & 40 & 3.48 & 0.93 & 0.48 & 23.55 & 0.000 \\
\hline $\begin{array}{l}\text { Prospects of } \\
\text { reappointment }\end{array}$ & 40 & 3.58 & 1.06 & 0.58 & 21.34 & 0.000 \\
\hline $\begin{array}{l}\text { Non-existence of an } \\
\text { audit committee }\end{array}$ & 40 & 3.48 & 0.85 & 0.48 & 25.95 & 0.000 \\
\hline
\end{tabular}

$\mathrm{N}=$ Number of observations.

The test confirms previous findings. All remaining threats are statistically significant. Moreover, bribery is the most potent threat to independence.

\section{Conclusion}

This study evaluates threats to auditor independence in Iran through the distribution of a mixed questionnaire to Iranian professionals and thematic 9analysis of media articles. Findings show that participants consider bribery, followed by prospects of reappointment as the most severe threats. Long-term relationship and non-existence of an audit committee are equally the next important threats. However, gifts and presents, and auditors' lack of competence 
are not threats. Moreover, participants perceive non-audit services and Iran's economic condition as other threats to independence. The consideration of bribery as the strongest threat shows its entrenched position within Iranian businesses and a need to introduce advanced strategies to safeguard businesses against it. The Iranian government should introduce advanced strategies to safeguard the country against bribery. This will eventually enhance auditor independence. High losses caused by corrupt practices encourage authorities to concentrate on issues of corruption and create some practical plans to minimise it. They need to introduce better regulations to address the corruption concerns in Iran.

The nomination of Iran's economic condition by participants as a threat shows the influence of the economic factors on business people's behaviour. The undesirable economic condition of the country is acknowledged, through analysis of the media articles. This analysis suggests the implementation of practical ways to improve the economic condition of the country. A better economic condition reduces the need for all participants in business activity to use illegal or immoral methods to conduct their business, increasing the overall health of the capital market. The government may need to think of some solutions to reduce the unemployment rate of auditors and increase their income level. The audit regulations may need to provide some financial safeguards for auditors. The provision of more job opportunities to auditors reduces their desire to succumb to management pressure, increasing their independence. Similarly, higher levels of income increase auditors' persistence against the management's fraudulent requests.

The nomination of non-audit services as threats suggests to the Iranian regulator to place more emphasis on them and introduce new rules to restrict them. Because non-audit services are widely acknowledged as threats to auditor independence in international literature, Iran's new aspiration to join the international community may encourage its regulator to introduce similar rules as those in IFRS countries to regulate non-audit services. The consideration of nonaudit services as potential threats may improve auditor independence in Iran. Similarly, the participants of this study's consideration of prospects of reappointment, long-term relationship, non-existence of audit committee, and auditors' lack of competence as threats recommend to the Iranian regulator to align audit regulations to those of IFRS countries. The regulator should consider this study's identified threats as potential threats to auditor independence. However, disregard of gifts and presents as threats reminds us of the importance of cultural factors in a business environment. The regulator should also align audit regulations with cultural perceptions of people. It may need, while aligning the rules, to help Iran to join the international community, consider specific cultural factors too.

IAO has not ranked in order of priority the 11 identified threats to auditor independence in Iran (see Section 1). This study recommends some improvements to the current IAO's independence framework, as follows:

Bribery should remain as the strongest threat in the framework.

A long-term relationship between auditors and their clients (which covers audit partner tenure and prospects of reappointment) should remain as the second strongest threat in the framework. 
The non-existence of an audit committee should be included as the third strongest threat in the framework.

Non-audit services should remain as priority threats.

High management pressure on auditors (which relates to prospects of reappointment), and high audit fees (which is an identified category of the openended question) should remain in the framework as priority threats.

Acceptance of gifts and presents; family, personal, or financial relationship between auditors and their clients; inclusion of auditors in their clients' board of directors, senior officers, or partners; existence of contingent fees; ownership of audit firms by those other than auditors; presence of former audit partners as clients; and existence of lawsuits between auditors and their clients should remain as non-priority threats in the framework.

This study contributes to a better understanding of auditor independence in Iran, which may apply to other regional settings. Moreover, it provides some suggestions to improve the current IAO's independence framework. However, it suffers from some limitations. First, many Iranian audit firms are not computerised (Salehi, Rostami, \& Mogadam, 2010). So, a paper-based questionnaire was used. The capacity to collect data was reduced, and it was time-consuming. Second, 40 responses were obtained in total, reducing the credibility of the outcomes of this study. For example, Salehi et al. (2009a) obtain 441 responses, Ramazani and Atani (2010) 178 responses, and Salehi (2011) 150 responses in other comparable Iranian studies. Third, the obtained data are limited to the city of Tehran and do not provide any information regarding the practitioners' perceptions in other Iranian cities. Fourth, this study used an agent in Iran, which prevents it from verifying that the testing has occurred in a controlled environment. For example, it is unclear whether or not audit firms that agreed to participate had any input into their participants, which may have biased their responses.

This study provides several avenues for future research. First, a more comprehensive analysis of media articles may provide better capacity for triangulation of outcomes of the questionnaire. Second, future studies may evaluate other threats that IAO has identified and obtain participants' views in other Iranian cities than Tehran. Third, future broad-scale studies of the effects of the Iranian culture on other aspects of the audit profession is another avenue. Fourth, an assessment of the best possible regulations to address non-audit services and an analysis of their implementation barriers are desirable. Fifth, future studies may analyse the effects of Iran's economic condition on other aspects of the audit profession.

\section{References}

Abdel-Khalik, A. R. (1990). The jointness of audit fees and demand for MAS: A selfselection analysis. Contemporary accounting research Vol. 6 No. 2 pp. 295-322.

Abdoli, M. R., Mahmoudzadeh, A., \& Darvishan, M. (2014). Assessing the effects of auditing institutions' size and type of auditors' opinion on auditing institutions' rotation. Stud Vol. 4 No. 1 pp. 01-05. 
Aghaei, M. A., \& Ranjbar, I. (2016). Presenting a structural equation model for effects of auditor independence on audit quality from managers' perspective of companies in Tehran Stock Exchange. Mediterranean Journal of Social Sciences Vol. 7 No. 2 S2 pp. 78-86.

Anonymous. (2011, 05 June 2011). In Islamic culture, gift-giving is an art. Daily News. Retrieved from http://www.dailynews.com/arts-and-entertainment/20110605/inislamic-culture-gift-giving-is-an-art

Anonymous. (2014a). Rate of unemployment in Iran-IMF. Pakistan \& Gulf Economist Vol. 33 No. 37 pp. $46-47$.

Anonymous. (2014b). Rouhani stabilises Iran's economy-IMF. Pakistan \& Gulf Economist Vol. 33 No. 33 pp. 50.

AoE. (1979). Constitution of the Islamic Republic of Iran. In. Tehran, Iran: Assembly of Experts.

APB. (2009). Long association with the audit engagement. In Ethical Standard 3 (pp. 111). London: Financial Reporting Council.

Arjomand, S. A. (2002). The reform movement and the debate on modernity and tradition in contemporary Iran. International Journal of Middle East Studies Vol. 34 No. 4 pp. 719-731.

Arowosaiye, Y. I. (2008). Economic and financial crimes and ICT infrastructure: The Islamic criminal law perspective. Paper presented at the 3rd International Conference on Postgraduate Education, Penang, Malaysia.

Arrunada, B., \& Paz-Ares, C. (1997). Mandatory rotation of company auditors: A critical examination. International Review of Law and Economics Vol. 17 No. 1 pp. 31-61.

Ashbaugh, H., LaFond, R., \& Mayhew, B. W. (2003). Do nonaudit services compromise auditor independence? Further evidence. The Accounting Review Vol. 78 No. 3 pp. 611-639.

Assembly of Experts. (1979). Constitution of the Islamic Republic of Iran. Retrieved from http://www.mut.ac.ir/legal/asasi.pdf

Au, A. K., \& Wong, D. S. (2000). The impact of guanxi on the ethical decision-making process of auditors-an exploratory study on Chinese CPAs in Hong Kong. Journal of Business Ethics Vol. 28 No. 1 pp. 87-93.

Azizkhani, M., Shailer, G., \& Monroe, G. (2012). The competitive pricing of audit services in a non-Big 4 market. Working paper. ANU College of Business and Economics. Australian National University. Canberra, ACT.

Babbie, E. (2007). The basics of social research (4 ed.). Boston, U.S.: Cengage Learning.

Bagranoff, N. A., \& Vendrzyk, V. P. (2000). The changing role of IS audit among the big five US-based accounting firms. Information Systems Control Journal Vol. 5 pp. 3337.

Barnes, P., \& Huan, H. D. (1993). The auditor's going concern decision: Some UK evidence concerning independence and competence. Journal of Business Finance \& Accounting Vol. 20 No. 2 pp. 213-228.

Baruch, Y., \& Holtom, B. C. (2008). Survey response rate levels and trends in organisational research. Human relations Vol. 61 No. 8 pp. 1139-1160.

Baskerville, R. F., Wynn-Williams, K., Evans, E., \& Gillett, S. (2014). Researching ethnicity in the Pacific Region. Pacific Accounting Review Vol. 26 No. 3 pp. 302323.

BBC. (2008, 25 June 2008). Iran leader calls for continuation of campaign against financial corruption. BBC Monitoring Middle East.

Beattie, V., Brandt, R., \& Fearnley, S. (1999). Perceptions of auditor independence: UK evidence. Journal of International Accounting, Auditing and Taxation Vol. 8 No. 1 pp. 67-107. 
Beattie, V., Fearnley, S., \& Brandt, R. (2004). A grounded theory model of auditor-client negotiations. International Journal of Auditing Vol. 8 No. 1 pp. 1-19.

Beck, P. J., Frecka, T. J., \& Solomon, I. (1988a). An empirical analysis of the relationship between MAS involvement and auditor tenure: Implications for auditor independence. Journal of Accounting Literature Vol. 7 No. 1 pp. 65-84.

Beck, P. J., Frecka, T. J., \& Solomon, I. (1988b). A model of the market for MAS and audit services: Knowledge spillovers and auditor-auditee bonding. Journal of Accounting Literature Vol. 7 No. 1 pp. 50-64.

Beeman, W. O. (2003). Iran and the United States: Postmodern culture conflict in action. Anthropological Quarterly Vol. 76 No. 4 pp. 671-691.

Bell, T. B., Causholli, M., \& Knechel, W. R. (2015). Audit firm tenure, non-audit services, and internal assessments of audit quality. Journal of Accounting Research Vol. 53 No. 3 pp. $461-509$.

Berton, L. (1991, 27 March 1991). GAO weighs auditing plan for big banks: Accounting firms express concern about proposal to require rotations. Wall Street Journal, p. A3.

Best, P. J., Buckby, S., \& Tan, C. (2001). Evidence of the audit expectation gap in Singapore. Managerial Auditing Journal Vol. 16 No. 3 pp. 134-144.

Betteridge, A. H. (1985). Gift exchange in Iran: The locus of self-identity in social interaction. Anthropological Quarterly Vol. 58 No. 4 pp. 190-202.

Bhasin, M. (2013). Corporate accounting scandal at Satyam: A case study of India's Enron. European Journal of Business and Social Sciences Vol. 1 No. 12 pp. 25-47.

Black, A., \& Sadiq, K. (2011). Good and Bad Sharia: Australia's Mixed Response to Islamic Law. University of New South Wales Law Journal, The Vol. 34 No. 1 pp. 383-412.

Bleibtreu, C., \& Stefani, U. (2013). The effects of mandatory auditor rotation on low balling behaviour and auditor independence. Working paper. Department of Economics. University of Konstanz. Konstanz, Baden-Württemberg.

Bochner, S., \& Hesketh, B. (1994). Power distance, individualism/collectivism, and jobrelated attitudes in a culturally diverse work group. Journal of cross-cultural psychology Vol. 25 No. 2 pp. 233-257.

Bozorgmehr, N. (2012). Iran warned over mounting unemployment. FT.com.

Branson, L., Chen, L., \& Anderson, L. (2015). The implementation of international codes of ethics among professional accountants: Do national cultural differences matter? International Journal of Business and Public Administration (IJBPA) Vol. 12 No. 1 pp. 1-12.

Callender, J. C., \& Osburn, H. (1979). An empirical comparison of Coefficient Alpha, Guttman's Lambda - 2, and MSPLIT Maximized Split-Half reliability estimates. Journal of Educational Measurement Vol. 16 No. 2 pp. 89-99.

Campa, D., \& Donnelly, R. (2016). Non-audit services provided to audit clients, independence of mind and independence in appearance: Latest evidence from large UK listed companies. Accounting and business Research Vol. 46 No. 4 pp. $422-449$.

Carcello, J. V., \& Nagy, A. L. (2004). Audit firm tenure and fraudulent financial reporting. Auditing: A Jounal of Practice \& Theory Vol. 23 No. 2 pp. 55-69.

Carcello, J. V., \& Neal, T. L. (2003). Audit committee characteristics and auditor dismissals following "new" going concern reports. The Accounting Review Vol. 78 No. 1 pp. 95-117.

Carey, P., \& Simnett, R. (2006a). Audit partner tenure and audit quality. The Accounting Review Vol. 81 No. 3 pp. 653-676.

Carey, P. J., \& Simnett, R. (2006b). Audit partner tenure and audit quality. The Accounting Review Vol. 81 No. 3 pp. 653-676. 
Carrera, N., Gómez-Aguilar, N., Humphrey, C., \& Ruiz-Barbadillo, E. (2007). Mandatory audit firm rotation in Spain: A policy that was never applied. Accounting, Auditing \& Accountability Journal Vol. 20 No. 5 pp. 671-701.

Causholli, M., Chambers, D. J., \& Payne, J. L. (2014). Future non-audit service fees and audit quality. Contemporary accounting research Vol. 31 No. 3 pp. 681-712.

Causholli, M., Chambers, D. J., \& Payne, J. L. (2015). Does selling non-audit services impair auditor independence? New research says,"Yes". Current Issues in Auditing Vol. 9 No. 2 pp. P1-P6.

Chatterjee, B., Mirshekary, S., Al Farooque, O., \& Safari, M. (2010). Users' information requirements and narrative reporting: The case of Iranian companies. Australasian Accounting, Business and Finance Journal Vol. 4 No. 2 pp. 79-96.

Chen, C. Y., Lin, C. J., \& Lin, Y. C. (2008). Audit partner tenure, audit firm tenure, and discretionary accruals: Does long auditor tenure impair earnings quality? Contemporary accounting research Vol. 25 No. 2 pp. 415-445.

Chi, W., Huang, H., Liao, Y., \& Xie, H. (2009). Mandatory audit-partner rotation, audit quality and market perception: Evidence from Taiwan. Contemporary accounting research Vol. 26 No. 2 pp. 359-391.

CIA. (2014). World factbook: Iran. Retrieved from https://www.cia.gov/library/publica tions/the-world-factbook/geos/ir.html\#Govt

Copley, P. A., \& Doucet, M. S. (1993). Auditor tenure, fixed fee contracts, and the supply of substandard single audits. Public Budgeting \& Finance Vol. 13 No. 3 pp. 23-35.

Craswell, A., Stokes, D. J., \& Laughton, J. (2002). Auditor independence and fee dependence. Journal of Accounting and Economics Vol. 33 No. 2 pp. 253-275.

Craswell, A. T. (1999). Does the provision of non-audit services impair auditor independence? International Journal of Auditing Vol. 3 No. 1 pp. 29-40.

Dao, M., Mishra, S., \& Raghunandan, K. (2008). Auditor tenure and shareholder ratification of the auditor. Accounting Horizons Vol. 22 No. 3 pp. 297-314.

DeFond, M. L., Raghunandan, K., \& Subramanyam, K. (2002). Do non-audit service fees impair auditor independence? Evidence from going concern audit opinions. Journal of Accounting Research Vol. 40 No. 4 pp. 1247-1274.

Dehghan, H. (2013). The auditors' duties against money laundering and economic corruption. European Online Journal of Natural and Social Sciences Vol. 2 No. 3 (s) pp. 798-808.

Ding, Y., Jeanjean, T., \& Stolowy, H. (2005). Why do national GAAP differ from IAS? The role of culture. The International Journal of Accounting Vol. 40 No. 4 pp. 325350 .

Dogui, K., Boiral, O., \& Heras-Saizarbitoria, I. (2014). Audit fees and auditor independence: The case of ISO 14001 certification. International Journal of Auditing Vol. 18 No. 1 pp. 14-26.

Dopuch, N., King, R. R., \& Schwartz, R. (2003). Independence in appearance and in fact: An experimental investigation. Contemporary accounting research Vol. 20 No. 1 pp. 79-114.

Dowling, C., \& Leech, S. A. (2014). A Big 4 firm's use of information technology to control the audit process: How an audit support system is changing auditor behaviour. Contemporary accounting research Vol. 31 No. 1 pp. 230-252.

Du, X. (2018). Hospitality and auditor independence: Do gifts blind the eyes? China Journal of Accounting Studies Vol. 5 No. 4 pp. 420-448.

Dunfee, T. W., \& Warren, D. E. (2001). Is guanxi ethical? A normative analysis of doing business in China. Journal of Business Ethics Vol. 32 No. 3 pp. 191-204. 
Durkin, P., \& King, A. (2012). ASIC threatens auditors with mandatory rotation. Accounting. Retrieved from http://www.afr.com/business/accounting/asic-threatensauditors-with-mandatory-rotation-20121204-jijuo

Earley, C. E., \& Kelly, P. T. (2004). A note on ethics educational interventions in an undergraduate auditing course: Is there an "Enron effect"? Issues in Accounting Education Vol. 19 No. 1 pp. 53-71.

Eshagniya, A., \& Salehi, M. (2017). The impact of financial restatement on auditor changes: Iranian evidence. Asia Pacific Journal of Innovation and Entrepreneurship Vol. 11 No. 3 pp. 366-390.

European Parliament. (2014). Regulation (EU) No 537/2014 of the European Parliament and of the Council of 16 April 2014 on specific requirements regarding statutory audit of public-interest entities and repealing commission decision 2005/909/EC. In (Vol. 114, pp. L 158/177-L 158/112). Brussels: Official Journal of the European Union.

Fan, Y. (2002). Ganxi's consequences: Personal gains at social cost. Journal of Business Ethics Vol. 38 No. 4 pp. 371-380.

Fashtami, M. (2014, 28 May 2014). Supreme Audit Court of Iran confirms government's taking $\$ 4.1$ billion out of NDF. McClatchy - Tribune Business News. Retrieved from https://en.trend.az/business/economy/2279051.html

Fern, F. (1985). Independence: An incomplete standard. The Internal Auditor Vol. 42 No. 5 pp. 30-35.

Francis, J. R., \& Ke, B. (2006). Disclosure of fees paid to auditors and the market valuation of earnings surprises. Review of Accounting Studies Vol. 11 No. 4 pp. 495523.

Franzel, J. M. (2012). Statement on public meeting on auditor independence and audit firm rotation. Retrieved from http://pcaobus.org/News/Speech/Pages/03212012_Franzel Statement.aspx

Gastwirth, J. L., Gel, Y. R., \& Miao, W. (2009). The impact of Levene's test of equality of variances on statistical theory and practice. Statistical Science Vol. 24 No. 3 pp. 343360.

Geiger, M. A., \& Raghunandan, K. (2002). Auditor tenure and audit reporting failures. Auditing: A Jounal of Practice \& Theory Vol. 21 No. 1 pp. 67-78.

Gholamhossin, M., \& Abdolhamid, H. (2012). The Impact of national auditing standards on the quality of auditors' opinions: Iranian experience. African Journal of Business Management Vol. 6 No. 29 pp. 8620-8629.

Gietzmann, M. B., \& Sen, P. K. (2002). Improving auditor independence through selective mandatory rotation. International Journal of Auditing Vol. 6 No. 2 pp. 183-210.

Gold, A., Klynsmit, P., Wallage, P., \& Wright, A. (2014). The impact of auditor selection regime and audit committee autonomy on investment decisions. Retrieved from http://www.isarhq.org/2014_downloads/papers/ISAR2014_Gold_Klynsmit_Wallage _Wright.pdf

Gregg, M. B. (2008). Field epidemiology. New York City, NY: Oxford University Press.

Hay, D., Knechel, R., \& Li, V. (2006a). Non-audit services and auditor independence: New Zealand evidence. Journal of business finance \& accounting Vol. 33 No. 5-6 pp. 715-734.

Hay, D. C., Knechel, W. R., \& Li, V. (2006b). Non-audit services and auditor independence: New Zealand evidence. Journal of Business Finance \& Accounting Vol. 33 No. 5-6 pp. 715-734.

Hayes, R. S., \& Schilder, A. (2005). Principles of auditing: An introduction to international standards on auditing (2 ed.). Upper Saddle River, New Jersey: Financial Times Prentice-Hall. 
He, X., Pittman, J. A., Rui, O. M., \& Wu, D. (2017). Do social ties between external auditors and audit committee members affect audit quality? The Accounting Review Vol. 92 No. 5 pp. 61-87.

Hilary, G., \& Lennox, C. S. (2005). The credibility of self-regulation: Evidence from the accounting profession's peer review program. Journal of Accounting and Economics Vol. 40 No. 1-3 pp. 211-229.

Hillmann, M. C. (1990). Iranian culture: A persianist view. University of Michigan, Ann Arbor, Michigan: University Press of America.

Ho, R. (2013). Handbook of univariate and multivariate data analysis with IBM SPSS (2 ed.). Hoboken: CRC Press.

Horvat, T., \& Lipičnik, M. (2016). Internal audits of frauds in accounting statements of a construction company. Strategic management Vol. 2 No. 4 pp. 29-36.

Hughes, S. B., Sander, J. F., Higgs, S. D., \& Cullinan, C. P. (2009). The impact of cultural environment on entry-level auditors' abilities to perform analytical procedures. Journal of International Accounting, Auditing and Taxation Vol. 18 No. 1 pp. 29-43.

Hwang, D. B., \& Staley, A. B. (2005). An analysis of recent accounting and auditing failures in the United States on U.S. accounting and auditing in China. Managerial Auditing Journal Vol. 20 No. 3 pp. 227-234.

IAO. (2014a). Approved code of professional conduct. Retrieved from http://www.audit. org.ir/WFrmCodificatedStandardComment.aspx?Id=Approved

IAO. (2014b). Approved code of professional conduct. In. Tehran: Iran Audit Organisation.

Ibrahim, S. S., Man, N. C., \& Noor, A. H. M. (2013a). Fraud: An Islamic perspective. Paper presented at the International Conference on Financial Criminology, Selangor.

Ibrahim, S. S., Man, N. C., \& Noor, A. H. M. (2013b). Fraud: An Islamic perspective. Paper presented at the International Conference on Financial Criminology, Selangor, Malaysia.

IFAC. (2013). Handbook of the code of ethics for professional accountants. In. New York City, NY: International Federation of Accountants.

IFAC. (2014a, June 2014). Handbook of the code of ethics for professional accountants. Retrieved from http://www.ifac.org/sites/default/files/publications/files/2014-IESBAHandbook.pdf

IFAC. (2014b). Handbook of the code of ethics for professional accountants. In. New York City, NY: International Federation of Accountants.

IFAC. (2018). About IFAC. Retrieved from http://www.ifac.org/about-ifac

IICA. (1985). Code of professional conduct. Retrieved from http://www.iranianica.com/

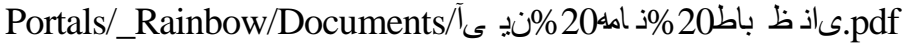

Iran Visitor. (2015) Iranian culture: Iranian etiquette \& manners. In, Your Tourist and Resident Guide to Iran. Tehran: Iran Tourist Info.

Ismail, A., \& Tohirin, A. (2010). Islamic law and finance. Humanomics Vol. 26 No. 3 pp. 178-199.

Javidan, M., \& Dastmalchian, A. (2003). Culture and leadership in Iran: The land of individual achievers, strong family ties, and powerful elite. The Academy of Management Executive Vol. 17 No. 4 pp. 127-142.

Jenkins, D. S., \& Vermeer, T. E. (2013). Audit firm rotation and audit quality: Evidence from academic research. Accounting Research Journal Vol. 26 No. 1 pp. 75-84.

Johnsen, Å., Robertsen, K., \& Äsland, D. Y. (2004). Contracting out municipal auditing conceptual framework and assessment. Evaluation Vol. 10 No. 3 pp. 305-326.

Johnson, V. E., Khurana, I. K., \& Reynolds, J. K. (2002). Audit-firm tenure and the quality of financial reports. Contemporary Accounting Research Vol. 19 No. 4 pp. 637-660. 
Kaiser, H. F. (1974). An index of factorial simplicity. Psychometrika Vol. 39 No. 1 pp. 3136.

KarbasiYazdi, H., \& ChenariYukat, H. (2012). Auditor rotation and administration period: Do auditors change? Journal of Auditing No. 63 pp. 68-69.

Kasim, N. (2010) Auditing from the Islamic perspective. In. Accountants Today (pp. 2831). Kuala Lumpur: Malaysian Institute of Accountants.

Khan, M. A. (1985). Role of the auditor in an Islamic economy. Journal of Research in Islamic Economics Vol. 3 No. 1 pp. 31-42.

Khan, M. A. (2011). Consumer protection and the Islamic law of contract. Islamabad Law Review Vol. 2 No. 2.

Khlif, H. (2016). Hofstede's cultural dimensions in accounting research: A review. Meditari Accountancy Research Vol. 24 No. 4 pp. 545-573.

Kinney Jr, W. R., \& McDaniel, L. (1996). How to improve effectiveness of substantive analytical procedures. The CPA Journal Vol. 66 No. 4 pp. 52-54.

Kinney, W. R., Palmrose, Z. V., \& Scholz, S. (2004). Auditor independence, non-audit services, and restatements: Was the US government right? Journal of Accounting Research Vol. 42 No. 3 pp. 561-588.

Klein, A. (2002). Audit committee, board of director characteristics, and earnings management. Journal of Accounting and Economics Vol. 33 No. 3 pp. 375-400.

Knapp, M. C. (1991). Factors that audit committee members use as surrogates for audit quality. Auditing: A Jounal of Practice \& Theory Vol. 10 No. 1 pp. 35-52.

Korkmaz, S., Goksuluk, D., \& Zararsiz, G. (2014). MVN: An R package for assessing multivariate normality. The R Journal Vol. 6 No. 2 pp. 151-162.

Kosmala, K. (2007). (Un)realised independence in the CEE region: Insights from interpretive cultural theory. Critical Perspectives on Accounting Vol. 18 No. 3 pp. 315-342.

Kozloski, T., Meckfessel, M., Moehrle, S. R., \& Williams, T. (2016). Developments in accounting regulation: A synthesis and annotated bibliography of evidence and commentary in the 2014 academic literature. Research in Accounting Regulation Vol. 28 No. 1 pp. $22-41$.

Krishnan, J., \& Ye, Z. (2005). Why some companies seek shareholder ratification on auditor selection. Accounting Horizons Vol. 19 No. 4 pp. 237-254.

Kwintessential Ltd. (2014). Iran: Language, culture, customs and etiquette. Retrieved from http://www.kwintessential.co.uk/resources/global-etiquette/iran-country-profile.html

Kwon, S. Y., Lim, Y. D., \& Simnett, R. (2010). Mandatory audit firm rotation and audit quality: Evidence from the Korean audit market. Working paper. Business School. University of New South Wales Sydney, NSW. Retrieved from http://www. researchgate.net/profile/Roger_Simnett/publication/228309948_Mandatory_Audit_F irm_Rotation_and_Audit_Quality_Evidence_from_the_Korean_Audit_Market/links/ 02e7e527eafc0c5c40000000.pdf

Law, P. (2010). The influence of the types of NAS provisions and gifts hospitality on auditor independence. International Journal of Accounting \& Information Management Vol. 18 No. 2 pp. 105-117.

Lee, T. A., \& Stone, M. (1995). Competence and independence: The congenial twins of auditing? Journal of Business Finance \& Accounting Vol. 22 No. 8 pp. 1169-1177.

Leech, N. L., Barrett, K. C., \& Morgan, G. A. (2012). IBM SPSS for intermediate statistics: Use and interpretation (4 ed.). Hoboken, NJ: Routledge.

Lennox, C. S., Wu, X., \& Zhang, T. (2014). Does mandatory rotation of audit partners improve audit quality? The Accounting Review Vol. 89 No. 5 pp. 1775-1803.

Levine, C. B., \& Kornish, L. J. (2000). Discipline with common agency: The case of audit and non-audit Services. Fuqua School of Business Vol. 79 No. 1 pp. 173-200. 
Levy, R. (1995). Corruption, economic crime and social transformation since the reforms: The debate in China. The Australian Journal of Chinese Affairs Vol. 33 No. 33 pp. 125.

Liang, Y. (2015). Evaluating market-based corporate governance reform: Evidence from a structural analysis of mandatory auditor rotation. School of Business. Temple University. Philadelphia, PA.

Lim, C. Y., \& Tan, H. T. (2010). Does auditor tenure improve audit quality? Moderating effects of industry specialization and fee dependence. Contemporary accounting research Vol. 27 No. 3 pp. 923-957.

Lonner, W. J., Berry, J. W., \& Hofstede, G. H. (1980). Culture's consequences: International differences in work-related values. University of Illinois at UrbanaChampaign's Academy for Entrepreneurial Leadership Historical Research Reference in Entrepreneurship. Champaign, IL.

López, M. A., Gabilondo, A., Codony, M., García-Forero, C., Vilagut, G., Castellví, P., . . . Alonso, J. (2013). Adaptation into Spanish of the Warwick-Edinburgh Mental Well-being Scale (WEMWBS) and preliminary validation in a student sample. Quality of Life Research Vol. 22 No. 5 pp. 1099-1104.

Lyon, J. D., \& Maher, M. W. (2005). The importance of business risk in setting audit fees: Evidence from cases of client misconduct. Journal of Accounting Research Vol. 43 No. 1 pp. 133-151.

Mansouri, A., Pirayesh, R., \& Salehi, M. (2009). Audit competence and audit quality: Case in emerging economy. International Journal of Business and Management Vol. 4 No. 2 pp. 17-25.

Mashayekhi, B., \& Mashayekh, S. (2008). Development of accounting in Iran. The International Journal of Accounting Vol. 43 No. 1 pp. 66-86.

McKinnon, J. (1984). Cultural constraints on audit independence in Japan. The International Journal of Accounting Vol. 20 No. 1 pp. 17-44.

Menold, N., Kaczmirek, L., Lenzner, T., \& Neusar, A. (2014). How do respondents attend to verbal labels in rating scales? Field Methods Vol. 26 No. 1 pp. 21-39.

Mironiuc, M., Chersan, I.-C., \& Robu, I.-B. (2013). The influence of the client's background on the auditor's decision in acceptance the audit engagement. Communications of the IBIMA, 2013, 1-16. Retrieved from http://www.ibimapubl ishing.com/journals/CIBIMA/2013/567289/567289.pdf doi:10.5171/2013.567289.

Mirshekary, S., \& Saudagaran, S. M. (2005). Perceptions and characteristics of financial statement users in developing countries: Evidence from Iran. Journal of International Accounting, Auditing and Taxation Vol. 14 No. 1 pp. 33-54.

Moghaddam, A.-a. G., Shadmehr, F., Mousavian, M., \& Minab, M. (2012). A review of history of accounting \& auditing in Iran. Arabian Journal of Business and Management Review (Oman Chapter) Vol. 2 No. 2 pp. 1-9.

MohammadRezaei, F., Mohd-Saleh, N., Jaffar, R., \& Hassan, M. S. (2016). The effects of audit market liberalisation and auditor type on audit opinions: The Iranian experience. International Journal of Auditing Vol. 20 No. 1 pp. 87-100.

Monroe, G., \& Ng, J. (2000). An examination of order effects in auditors' inherent risk assessments. Accounting \& Finance Vol. 40 No. 2 pp. 153-167.

Moore, D. A., Tetlock, P. E., Tanlu, L., \& Bazerman, M. H. (2006). Conflicts of interest and the case of auditor independence: Moral seduction and strategic issue cycling. Academy of Management Review Vol. 31 No. 1 pp. 10-29.

Myers, J. N., Myers, L. A., \& Omer, T. C. (2003). Exploring the term of the auditor-client relationship and the quality of earnings: A case for mandatory auditor rotation? The Accounting Review Vol. 78 No. 3 pp. 779-799. 
Nelson, M. W., Elliott, J. A., \& Tarpley, R. L. (2000). Where do companies attempt earnings management, and when do auditors prevent it? Paper presented at the AFA 2001 New Orleans Meetings, New Orleans, Louisiana.

Nur Barizah Abu, B., Abdul Rahim Abdul, R., \& Hafiz Majdi Abdul, R. (2005). Factors influencing auditor independence: Malaysian loan officers' perceptions. Managerial Auditing Journal Vol. 20 No. 8/9 pp. 804-822.

Osburn, H. G. (2000). Coefficient alpha and related internal consistency reliability coefficients. Psychological methods Vol. 5 No. 3 pp. 343-355.

Pai, K., \& Tolleson, T. D. (2015). India's Satyam scandal: Evidence the too large to indict mindset of accounting regulators is a global phenomenon. Review of Business \& Finance Studies Vol. 6 No. 2 pp. 35-43.

Palmrose, Z.-V. (1989). The relation of audit contract type to audit fees and hours. Accounting Review Vol. 64 No. 3 pp. 488-499.

Pany, K., \& Reckers, P. M. (1980). The effect of gifts, discounts, and client size on perceived auditor independence. The Accounting Review Vol. 55 No. 1 pp. 50-61.

Patel, C., Harrison, G. L., \& McKinnon, J. L. (2002). Cultural influences on judgments of professional accountants in auditor-client conflict resolution. Journal of International Financial Management \& Accounting Vol. 13 No. 1 pp. 1-31.

Petty, R., \& Cuganesan, S. (1996). Auditor rotation: Framing the debate. Companies could face higher fees and a decline in audit quality if law changes force them to rotate their auditors. Australian Accountant Vol. 66 No. 4 pp. 40-42.

Quick, R., \& Warming-Rasmussen, B. (2015). An experimental analysis of the effects of non-audit services on auditor independence in appearance in the European Union: Evidence from Germany. Journal of International Financial Management \& Accounting Vol. 26 No. 2 pp. 150-187.

Raghunandan, K. (2003). Nonaudit services and shareholder ratification of auditors. Auditing: A Journal of Practice \& Theory Vol. 22 No. 1 pp. 155-163.

Raghunandan, K., Rama, D. V., \& Read, W. J. (2001). Audit committee composition,"gray directors," and interaction with internal auditing. Accounting Horizons Vol. 15 No. 2 pp. 105-118.

Raghunathan, B., Lewis, B., \& Evans III, J. (1994). An empirical investigation of problem audits. Research in Accounting Regulation Vol. 8 No. 1 pp. 33-58.

Ramazani, M., \& Atani, H. R. (2010). Iranian accountants conception of the prevention methods of fraud and offering some recommendations to reduce fraud in Iran. Global Journal of Management and Business Research Vol. 10 No. 6 pp. 31-45.

Rankin, K. (2004). PCAOB reopens tax services debate. Accounting Today Vol. 18 No. 14 pp. 1-38.

Rezaee, Z., \& Davani, H. (2013). Does financial reporting fraud recognize borders? Evidence from bank fraud in Iran. Journal of Forensic \& Investigative Accounting Vol. 5 No. 2 pp. 1-18.

Rostami, A., Pakdel, G., Hasanzadeh Kojou, S., \& Hasanzadeh Kochou, M. (2016). Iranian GAAP and IFRS: The history and current status of IAS/IFRS convergence process in Iran. International Journal of Finance \& Managerial Accounting Vol. 1 No. 3 pp. 55-66.

Saeidi, F. (2012). Audit expectations gap and corporate fraud: Empirical evidence from Iran. African Journal of Business Management Vol. 6 No. 23 pp. 7031-7041.

Sainty, B. J., Taylor, G. K., \& Williams, D. D. (2002). Investor dissatisfaction toward auditors. Journal of Accounting, Auditing \& Finance Vol. 17 No. 2 pp. 111-136.

Salehi, M. (2009a). Corporate governance and audit independence: Empirical evidence of Iranian bankers. International Journal of Business and Management Vol. 3 No. 12 pp. 44-51. 
Salehi, M. (2009b). Non-audit service and audit independence: Evidences from Iran. International Journal of Business and Management Vol. 4 No. 2 pp. 142-152.

Salehi, M. (2011). Audit committee non-existing reasons: Evidence of Iran. Mediterranean J. Soc. Sci Vol. 2 No. 1 pp. 188-214.

Salehi, M., \& Abedini, B. (2008). Iranian angle: Worth of audit report. SCMS Journal of Indian Management Vol. 5 No. 2 pp. 82-90.

Salehi, M., \& Azary, Z. (2008). Fraud detection and audit expectation gap: Empirical evidence from Iranian bankers. International Journal of Business and Management Vol. 3 No. 10 pp. 65-77.

Salehi, M., \& Husini, R. (2011). A study of the effect of information technology on internal auditing: Some Iranian evidence. African Journal of Business and Management Vol. 5 No. 15 pp. 6169-6179.

Salehi, M., \& Kangarlouei, S. J. (2010). An investigation of the effect of audit quality on accrual reliability of listed companies on Tehran Stock Exchange. Review of International Comparative Management Vol. 11 No. 5 pp. 940-960.

Salehi, M., Mansouri, A., \& Azary, Z. (2009a). Audit independence and expectation gap: Empirical evidences from Iran. International Journal of Economics \& Finance Vol. 1 No. 1 pp. 165-174.

Salehi, M., Mansouri, A., \& Pirayesh, R. (2008). Factors affecting quality of audit: Empirical evidence from Iran. Journal of Business Research Vol. 2 No. 1-2 pp. 2432.

Salehi, M., Mansoury, A., \& Azary, Z. (2009b). Audit independence and expectation gap: Empirical evidences from Iran. International Journal of Economics \& Finance Vol. 1 No. 1 pp. 165-174.

Salehi, M., \& Nanjegowda, K. (2006). Audit expectation gap: The concept. Journal of Audit Practice Vol. 3 No. 4 pp. 69-73.

Salehi, M., Rostami, V., \& Mogadam, A. (2010). Usefulness of accounting information system in emerging economy: Empirical evidence of Iran. International Journal of Economics \& Finance Vol. 2 No. 2 pp. 186-195.

SEC. (2000). Final Rule: Revision of the commission's auditor independence requirements. In. Washington, D.C.: U.S. Securities and Exchange Commission.

SEC. (2002). The Sarbanes-Oxley Act of 2002. In Public Law 107-204 [H. R. 3763]. Washington, D.C.: GPO.

SEC. (2003). Strengthening the Commission's requirements regarding auditor independence. In Final Rule. Rel. No. 33-8183, File No.: S7-49-02. Washington, D.C.: U.S. Securities and Exchange Commission.

Shushter, M. (2011). Iran's largest banks swindled out of $\$ 2.6$ billion. Retrieved from http://www.npr.org/2011/10/27/141729872/irans-largest-banks-swindled-out-of-2-6billion

Sijtsma, K. (2009). On the use, the misuse, and the very limited usefulness of Cronbach's alpha. Psychometrika Vol. 74 No. 1 pp. 107-120.

Simon, D. T., \& Francis, J. R. (1988). The effects of auditor change on audit fees: Tests of price cutting and price recovery. Accounting Review Vol. 63 No. 2 pp. 255-269.

Simunic, D. A. (1984). Auditing, consulting, and auditor independence. Journal of Accounting Research Vol. 22 No. 2 pp. 679-702.

Smith, D. B., Stettler, H., \& Beedles, W. (1984). An investigation of the information content of foreign sensitive payment disclosures. Journal of Accounting and Economics Vol. 6 No. 2 pp. 153-162.

Snell, R. S. (1999). Obedience to authority and ethical dilemmas in Hong Kong companies. Business Ethics Quarterly Vol. 9 No. 3 pp. 507-526. 
Soliman, M. M., \& Ragab, A. A. (2014). Audit committee effectiveness, audit quality and earnings management: An empirical study of the listed companies in Egypt. Research Journal of Finance and Accounting Vol. 5 No. 2 pp. 155-166.

Stevenson, J. E. (2002). Auditor independence: A comparative descriptive study of the UK, France and Italy. International Journal of Auditing Vol. 6 No. 2 pp. 155-182.

Sudalaimuthu, S., \& Jesintha, P. (2011). Auditors perception towards International Financial Reporting Standards (IFRS): Benefits and key challenges. Indian Journal of Accounting Vol. 11 No. 2 pp. 27-35.

Tabibi, M. (1993). Inconsistency of auditors' method. Accountant's Monthly Vol. 101 No. 102 pp. 130-137 \& 186.

Tan, S. y., Hemmelgarn, M., Baumgardner, K., \& Tucker, R. M. (2017). Attitudes towards and experiences with research: Differences between dietetics students and professionals in Australia and the United States. Nutrition \& Dietetics Vol. 74 No. 4 pp. 388-395.

Taormina, R. J., \& Kin-Mei Lao, S. (2007). Measuring Chinese entrepreneurial motivation: Personality and environmental influences. International Journal of Entrepreneurial Behaviour \& Research Vol. 13 No. 4 pp. 200-221.

Teoh, H. Y., \& Lim, C. C. (1996). An empirical study of the effects of audit committees, disclosure of nonaudit fees, and other issues on audit independence: Malaysian evidence. Journal of International Accounting, Auditing and Taxation Vol. 5 No. 2 pp. 231-248.

The Economist Intelligence Unit N.A., I. (2014, Sep 2014). Country Forecast Iran September 2014. Retrieved from http://search.proquest.com.ezp01.library.qut. edu.au/docview/1562269023?accountid $=13380$

Transparency International. (2014). Corruption Perceptions Index. Retrieved from http://www.transparency.org/cpi2014

TSE. (2005). Legal structure. Retrieved from http://www.tse.ir/cms/default.aspx?tabid=57

TSE. (2006). History. Retrieved from http://www.tse.ir/cms/default.aspx?tabid=56

TSE. (2013, 11 Feb 2013). Audit committee charter. Retrieved from http://new.tse.ir/ cms/Portals/1/ghavanin/manshor-komiteh-hesabresi-\%5B91-11-23\%5D4520.pdf

Turow, S. (1985). What's wrong with bribery. Journal of Business Ethics Vol. 4 No. 4 pp. 249-251.

Umar, A., \& Anandarajan, A. (2004). Dimensions of pressures faced by auditors and its impact on auditors' independence: A comparative study of the USA and Australia. Managerial Auditing Journal Vol. 19 No. 1 pp. 99-116.

Van der Ark, L. A., Van der Palm, D. W., \& Sijtsma, K. (2011). A latent class approach to estimating test-score reliability. Applied Psychological Measurement Vol. 35 No. 5 pp. 380-392.

Watts, R. L., \& Zimmerman, J. L. (1983). Agency problems, auditing, and the theory of the firm: Some evidence. The Journal of Law \& Economics Vol. 26 No. 3 pp. 613 633.

Westphal, J. D., \& Stern, I. (2006). The other pathway to the boardroom: Interpersonal influence behaviour as a substitute for elite credentials and majority status in obtaining board appointments. Administrative science quarterly Vol. 51 No. 2 pp. 169-204.

Wicks, D. (2010). Coding: Axial coding. In A. J. Mills, G. Durepos, \& E. Wiebe (Eds.), Encyclopedia of case study research (Vol. 1-0). Thousand Oaks, CA: SAGE Publications, Inc.

Wright, R. (2000, Jan/Feb 2000). Iran's new revolution. Foreign Affairs, pp. 133-145. Retrieved from https://www.foreignaffairs.com/articles/iran/2000-01-01/irans-newrevolution 
Yamamura, J. H., Frakes, A. H., Sanders, D. L., \& Ahn, S. K. (1996). A comparison of Japanese and U.S. auditor decision-making behaviour. The International Journal of Accounting Vol. 31 No. 3 pp. 347-363.

Ybarra, M. J. (2011, 05 June 2011). ART; Islamic world's art of gift giving; A LACMA exhibition includes religious, political and personal presents offered by royal courts over the centuries. Los Angeles Times, p. 4. Retrieved from http://search.proquest. com.ezp01.library.qut.edu.au/docview/870214960?accountid=13380

Ye, P., Carson, E., \& Simnett, R. (2006). Threats to auditor independence: The impact of non-audit services, tenure and alumni affiliation. Working paper. School of Accounting. University of New South Wales. Sydney, NSW. 
Appendix 1. The Questionnaire of this Study

Section I. Demographic Information

What is your highest qualification level?

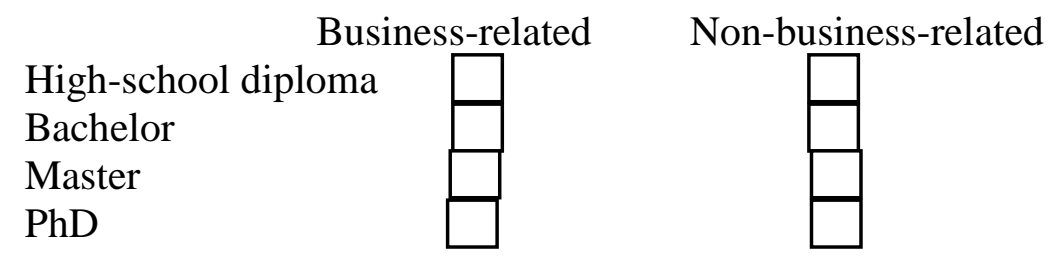

Do you have any professional accounting qualification?

Yes $\square \quad$ No $\square$

If yes:

Iranian Accounting Association

Iranian Association of Certified Public Accountants

Iranian Institute of Certified Accountants

If you have any other qualification indicate it, please:

Do you have any accounting experience?

Yes

No $\square$

If yes:

$1-3$ years

4 - 6 years

7 - 9 years

Over 10 years (Indicate the number of years, please):

Describe the type of accounting experience that you have, please:

What is your current occupation?

Regulator

Accountant

Auditor

Consultant

Investor

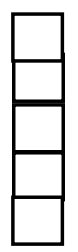


Other (Indicate your current occupation, please):

How long have you been in your current occupation?

1 - 3 years

$4-6$ years

7 - 9 years

Over 10 years (Indicate the number of years, please):

\section{Section II: Experience and Perception on Threats to Auditor Independence}

Each of the following presents a scenario of ethical issues. First, please mention any experience that you may have had regarding the specified ethical issues in your professional life. Then, please rank each scenario on a scale of one (1) as low to five (5) as high across the questions.

The Iranian Code of Professional Conduct considers the gifts and presentations as serious threats to auditor independence (Term: 21.13). The Code indicates that the auditors should refrain from accepting or giving any gifts or presentations that may affect their professional judgement (Term: 15.2.E).

Have you ever had any experience regarding gifts and presentations in your professional life?

Yes $\square \quad$ No $\square$

How much of monetary value of a gift is more than a reasonable amount in your opinion?

$\$ 0$

$\$ 50$ or less

$\$ 100$ or less

$\$ 200$ or less

Higher (Indicate the value, please):

Gifts and presentations are

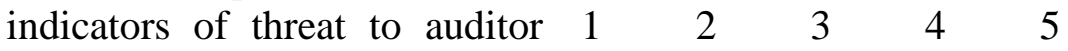
independence in Iran.
Gifts and presentations are not indicators of threat to auditor independence in Iran.

Article 49 of the Iranian Constitution requires the Iranian government to confiscate the wealth obtained from bribery and return it to its legitimate owner. Further, the Iranian Institute of Certified Accountants Code of Professional Conduct considers the moral characteristics of accountants as the most important part of their profession.

Have you ever had any experience regarding bribery in your professional life?

Yes $\square \quad$ No $\square$

Bribery is an indicator of threat to auditor independence in Iran.
Bribery is not an indicator of threat to auditor independence in Iran. 
According to the Iranian Code of Professional Conduct a long-term relationship between the auditors and their clients may threat auditor independence. In such circumstances, the auditors should take the necessary measures to safeguard their independence.

What is the longest duration of a relationship between the auditors and their clients that you have ever seen in your professional life?

5 years or less

7 years or less

10 years or less

Other (Indicate the number of years, please):

Long-term relationship is an

indicator of threat to auditor $\begin{array}{lllllll}1 & 2 & 3 & 4 & 5\end{array}$

independence in Iran.

Long-term relationship is not an indicator of threat to auditor independence in Iran.

The academic literature suggests that the prospect of reappointment can endanger auditor independence, since the auditors may sacrifice their commitments in order to continue receiving their audit fees.

The prospect of reappointment

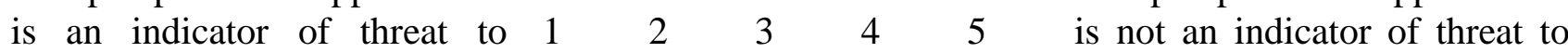
auditor independence in Iran. auditor independence in Iran.

According to the Tehran Stock Exchange regulations, audit committees assist the Board of Directors regarding internal control and risk management, financial reporting, internal audit effectiveness, independent audit effectiveness, and compliance with the rules, provisions, and requirements.

Have you ever had any experience regarding working with an audit committee in your professional life?

Yes $\square$ No $\square$ non-existence of audit committee is an indicator of $\begin{array}{lllll}1 & 2 & 3 & 4 & 5\end{array}$ threat to auditor independence in Iran.

The non-existence of audit committee is not an indicator of threat to auditor independence in Iran.

According to the Iranian Code of Professional Conduct the auditors should have the required skills to perform their duties. They should consistently maintain their professional knowledge and skill of regulations and changes in the profession.

The auditor lack of skill is an indicator of threat to auditor $\begin{array}{llllll}1 & 2 & 3 & 4 & 5\end{array}$ independence in Iran.

The auditor lack of skill is not an indicator of threat to auditor independence in Iran. 
Section III: Additional Comments on Threats to Auditor Independence in Iran

Are there any other factors that are indicators of threat to auditor independence in Iran in your opinion?

Yes $\square \quad$ No $\square$

If yes indicate them, please: 